\title{
$\beta 2$-Adrenergic Signalling Promotes Cell Migration by Upregulating Expression of the Metastasis-Associated Molecule LYPD3
}

\author{
Michael Gruet ${ }^{1,+}{ }^{+}$, Daniel Cotton ${ }^{1,2,+}$, Clare Coveney $^{1}{ }^{\text {, David J. Boocock }}{ }^{1}{ }^{\mathbb{D}}$, Sarah Wagner ${ }^{1}$, \\ Lucie Komorowski ${ }^{1}$, Robert C. Rees ${ }^{1}$, A. Graham Pockley ${ }^{1}$, A. Christopher Garner ${ }^{2}$, \\ John D. Wallis ${ }^{2}$, Amanda K. Miles ${ }^{1, *,+}$ iD and Desmond G. Powe 1,3,t $^{1}$ \\ 1 John van Geest Cancer Research Centre, Nottingham Trent University, Nottingham NG11 8NS, UK; \\ michaelgruet@hotmail.co.uk (M.G.); Daniel_Cotton@hotmail.co.uk (D.C.); Clare.Coveney@ntu.ac.uk (C.C.); \\ david.boocock@ntu.ac.uk (D.J.B.); sarah.wagner@ntu.ac.uk (S.W.); lucie.komorowski@gmail.com (L.K.); \\ robert.rees@ntu.ac.uk (R.C.R.); graham.pockley@ntu.ac.uk (A.G.P.); des.powe@talktalk.net (D.G.P.) \\ 2 School of Science and Technology, Nottingham Trent University, Nottingham NG11 8NS, UK; \\ christopher.garner@ntu.ac.uk (A.C.G.); john.wallis@ntu.ac.uk (J.D.W.) \\ 3 Department of Cellular Pathology, Queen's Medical Centre, Nottingham University Hospitals NHS Trust, \\ Derby Road, Nottingham NG7 2UH, UK \\ * Correspondence: amandakcartwright1978@gmail.com; Tel.: +44-(0)115-848-3754 \\ + These authors contributed equally.
}

Received: 13 January 2020; Accepted: 20 February 2020; Published: 22 February 2020

check for updates

\begin{abstract}
Metastasis is associated with poor prognosis in breast cancer. Although some studies suggest beta-blockers increase survival by delaying metastasis, others have been discordant. This study provides both insights into the anomalous findings and identifies potential biomarkers that may be treatment targets. Cell line models of basal-type and oestrogen receptor-positive breast cancer were profiled for basal levels of adrenoceptor gene/protein expression, and $\beta 2$-adrenoceptor mediated cell behaviour including migration, invasion, adhesion, and survival in response to adrenoceptor agonist/antagonist treatment. Protein profiling and histology identified biomarkers and drug targets. Baseline levels of adrenoceptor gene expression are higher in basal-type rather than oestrogen receptor-positive cancer cells. Norepinephrine (NE) treatment increased invasive capacity in all cell lines but did not increase proliferation/survival. Protein profiling revealed the upregulation of the pro-metastatic gene Ly6/PLAUR Domain-Containing Protein 3 (LYPD3) in norepinephrine-treated MDA-MB-468 cells. Histology confirmed selective LYPD3 expression in primary and metastatic breast tumour samples. These findings demonstrate that basal-type cancer cells show a more aggressive adrenoceptor- $\beta 2$-activated phenotype in the resting and stimulated state, which is attenuated by adrenoceptor- $\beta 2$ inhibition. This study also highlights the first association between ADR $\beta 2$ signalling and LYPD3; its knockdown significantly reduced the basal and norepinephrine-induced activity of MCF-7 cells in vitro. The regulation of ADR $\beta 2$ signalling by LYPD3 and its metastasis promoting activities, reveal LYPD3 as a promising therapeutic target in the treatment of breast and other cancers.
\end{abstract}

Keywords: breast cancer; $\beta 2$-adrenoceptor; beta-blockers; LYPD3

\section{Introduction}

Metastasis is critical in the progression of breast cancer and is frequently associated with poor prognosis. Although strategies that inhibit metastasis will increase progression-free survival (PFS), the identification of therapeutic druggable targets that prevent metastasis remain in its infancy [1]. 
Approaches for preventing metastasis require drugs that have cytostatic rather than cytotoxic properties, and are principally aimed at suppressing progression along the multistep metastasis pathway [2].

The repurposing of beta-adrenergic receptor antagonists (beta-blockers) as an adjuvant therapy for the treatment of breast cancer has been proposed on the basis of their anti-metastatic properties [3-5]. In vitro and in vivo models have demonstrated propranolol-induced inhibition of cancer cell signalling pathways decreases cell adhesion, migration, invasion, extravasation and colonisation in distant tissues including bone [6-8], thereby leading to reduced metastasis [9]. These pathways are triggered by catecholamine hormones such as norepinephrine acting on beta ( $\beta-)$ adrenergic G-protein coupled receptors (GPCR) expressed on breast cancer cells. Epidemiology studies observing the therapeutic potential of beta-blockers for treating breast cancer have revealed an association between (coincidental) beta-blocker usage and survival benefits [10-12]. The clinical evaluation of propranolol as a neoadjuvant or perioperative treatment for breast cancer is on-going [13-16]. However, a recent contradictory study has reported no benefit between prescribed beta-blockers and survival [17], whereas a different study using the basal-type MDA-MB-231 breast cancer cell line model showed that beta-adrenergic receptor (ADR $\beta 2)$ agonism (rather than antagonism) inhibited tumour proliferation [18]. Further studies are required to explain these discordant findings, which could result from variance in (a) in vitro cell line models; (b) patient cohort selected in pre-clinical studies; (c) pharmacologic selectivity of prescribed beta-blockers.

In this study, adrenoceptor expression and $\beta 2$-adrenoceptor-mediated metastasis-associated cell behaviour were examined in three frequently used in vitro cell line models of 'stress-induced' triple-negative basal-type breast cancer and compared to a popular oestrogen-positive cell line model. $\beta 2$-adrenoceptor-induced proteomic changes were assessed to better understand ADR-mediated cancer pathways, and provide biomarker and therapeutic treatment target identification. The study reveals complex and distinct differences between the cell lines and also identified a link between ADR $\beta 2$ signalling and LYPD3; revealing LYPD3 as a potential key mediator in ADR $\beta 2$ driven metastasis.

\section{Results}

\subsection{Basal-Type Breast Cancer Cell Lines Express Higher Levels of Functional $\beta 2$-Adrenoceptor and Their Survival Is Not Significantly Altered Following Non-Selective ADR $\beta$ Activation}

The steady state mRNA expression of each ADR subtype was assessed in unstimulated breast cancer cell lines. $\beta 2$-adrenoceptor gene expression was highest in the unstimulated MDA-MB-231 basal cell line, followed by MDA-MB-468 and BT-549. Negligible expression was observed in the ER-positive MCF-7 cell line (Figure 1A). To evaluate the cell surface expression of the selected ADRs, flow cytometry was performed. The level of membranous ADR $\beta 2$ expression was highest in the unstimulated basal cell line MDA-MB-468 although levels were very similar between this cell line and MDA-MB-231 and MCF-7. BT-549 cells expressed the lowest levels of ADR 32 (Figure 1B). These results show that the cell lines, in our hands, express ADRs at both the mRNA and protein levels. All cell lines treated with the non-selective ADR $\beta$ agonist isoproterenol showed elevated accumulation of intracellular cAMP (MDA-MB-231 > MDA-MB-468 > BT-549 > MCF-7) (Figure 1C), confirming functional ADR. Furthermore, simultaneous treatment with norepinephrine and the ADR $\beta 2$ selective antagonist ICI-118,551 had no significant effect on cell survival at therapeutically relevant concentrations compared to treatment of the cells with norepinephrine alone (Supplementary Materials Figure S1). These results demonstrate that any change in cell migration/invasion observed following ADR agonism/antagonism is not due to the compounds affecting cell survival. 
(A)

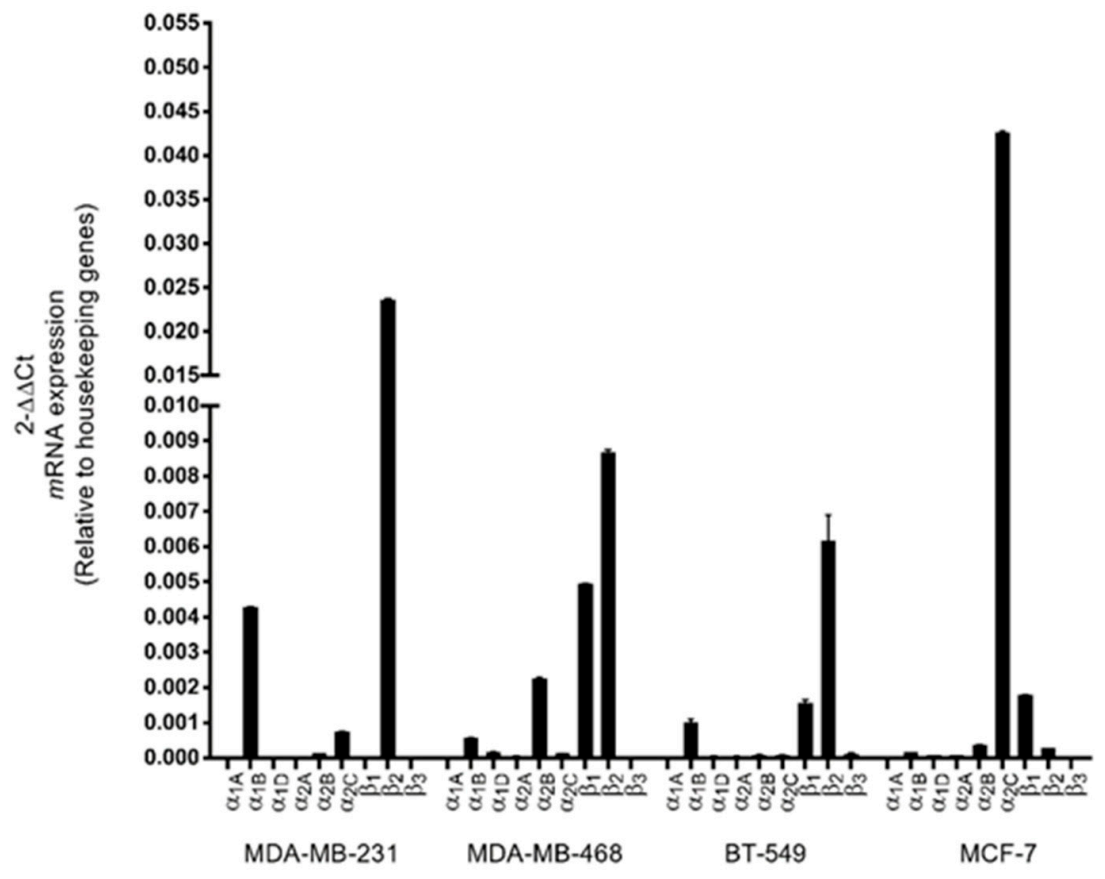

(B)

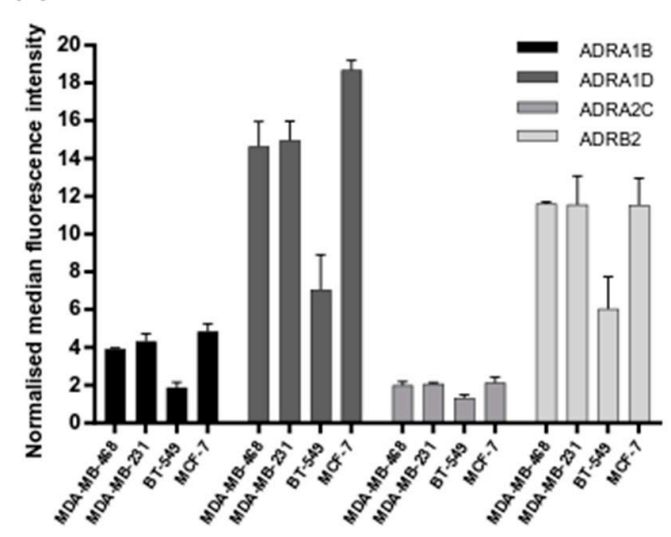

(C)

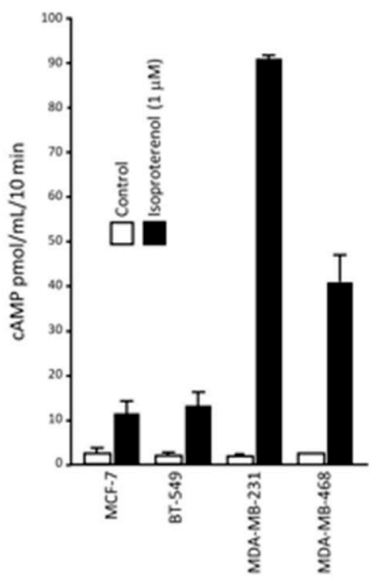

Figure 1. Adrenoceptor (ADR) expression on breast cancer cells and measurement of cAMP (cyclic adenosine monophosphate) levels following adrenergic stimulation. (A) Relative expression of ADR mRNA in breast cancer cell lines was quantified by qRT-PCR (quantitative reverse transcription polymerase chain reaction) and relative expression $\left(2^{-\Delta \Delta C T}\right)$ was determined by normalisation to housekeeping genes. $\beta 2$-adrenoceptor gene expression was strongest in the basal-type cell lines MDA-MB-231 and MDA-MB-468. (B) Expression of the adrenoceptors on unpermeabilised breast cancer cells was assessed by measuring median fluorescence intensity (MFI) using flow cytometry. Membranous $\beta 2$-adrenoceptor protein expression was highest in the basal-type cell line MDA-MB-468, followed by MDA-MB-231 > MCF-7 > BT-549. (C) Isoproterenol ( $\beta$-agonist) stimulated cAMP accumulation in breast cancer cell lines. Cells were treated in the presence of IBMX to prevent cAMP degradation. cAMP production was highest in the order MDA-MB-231 > MDA-MB-468 > BT-549 > MCF-7. All assays were performed in triplicate $(n=3)$. Results shown are the mean \pm standard deviation. 


\subsection{Substrate-Modulated Cell Adhesion/Migration/Invasion Responses Are ADR $\beta$-Dependent}

The ability of ADR agonist and antagonist compounds to modulate different parameters associated with metastasis were assessed.

\subsubsection{Cell Adhesion}

Cell-cell and cell-substrate adhesion characteristics play a pivotal role in many of the key steps of the metastatic cascade and in the metastatic cascade, cells alter their adhesive capacity during transmigration, intravasation and extravasation. The observed increases in adhesive capacity induced by norepinephrine and isoproterenol are mediated by the $\beta 1$-integrins. Strell et al. also concluded that two possible routes of treatment for the inhibition of MDA-MB-231 cell adhesion to lung epithelial cells is to either block $\beta 2$-adrenoceptor signalling or to block the action of the $\beta 1$-integrins [7].

Although the use of tissue culture plastic can provide an insight into the adhesive capacity of cells, its use does not appropriately reflect the extracellular matrix proteins that make up the surfaces of the tumour microenvironment and other important areas of the body that cells may encounter during the metastatic cascade. Fibronectin, vitronectin and collagen I are among the most abundant extracellular matrix proteins and are among the key ligands of the crucial adhesion-regulating integrins, therefore, the influence norepinephrine has on breast cancer cells adhering to these substrates was investigated.

Simultaneous treatment with norepinephrine and the ADR $\beta$ selective antagonist ICI-118,551 reduced the adhesion in all four cell lines grown on collagen I and vitronectin coated surfaces $(p<0.05)$. The adhesion of the basal-type MDA-MB-468 and MDA-MB-231 cell lines to fibronectin-coated surfaces was also reduced $(p<0.01)$ (Figure 2A and Supplementary Materials Figure S2). These results indicate that the adhesion of breast cancer cells can vary according to the surface on which they are grown.

\subsubsection{Cell Migration}

The ADR $\beta$ selective antagonist ICI-118,551 completely abrogated the enhanced migration of MDA-MB-468, BT-549 and MCF-7 cells induced by norepinephrine treatment, as assessed using scratch migration assays (Supplementary Materials Figure S3). When the migration of cells through an $8 \mu \mathrm{m}$ porous membrane was assessed, norepinephrine caused a significant increase in the migration of MDA-MB-468 cells $(p<0.01)$ and this increase was completely reversed by the concomitant administration of ICI-118,551 ( $p<0.01$ ) (Figure 2B). Interestingly, norepinephrine treatment significantly reduced the migration of MDA-MB-231 cells when grown on both uncoated plastic (Supplementary Materials Figure S3) and when migrating through a porous membrane $(p<0.01)$ (Figure 2B). Treatment with ICI-118,551 alone reduced migration, albeit non-significantly (Figure 2B). Whilst there was an increase in migration of BT-549 and MCF-7 cells following norepinephrine stimulation and a subsequent decrease following concomitant ICI-118,551 administration, this was not statistically significant. These observations were confirmed and were statistically significant in our scratch assay data (Supplementary Materials Figure S3), which leads us to believe that this technique for measuring cell migration may not be the best method for every cell line. These findings reinforce the need for investigating the invasive behaviour of cells using a more biologically relevant model and whilst in vivo models would answer these questions, it is important to try and identify a relevant in vitro model before animal models are used.

\subsubsection{Cell Invasion}

Norepinephrine stimulation alone significantly increased the invasive capacity of all breast cancer cell lines through a basement protein-coated membrane $(p<0.05)$. Furthermore, treatment with the ICI-118,551 antagonist significantly decreased the invasive capacity of MDA-MB-468, MDA-MB-231, BT-549 and MCF-7 cell lines ( $p$ <.05) (Figure 2C), suggesting that our cell line models are able to recapitulate what others in the literature have observed and provide a sound model to investigate proteomic changes following ADR agonism/antagonism [19]. 

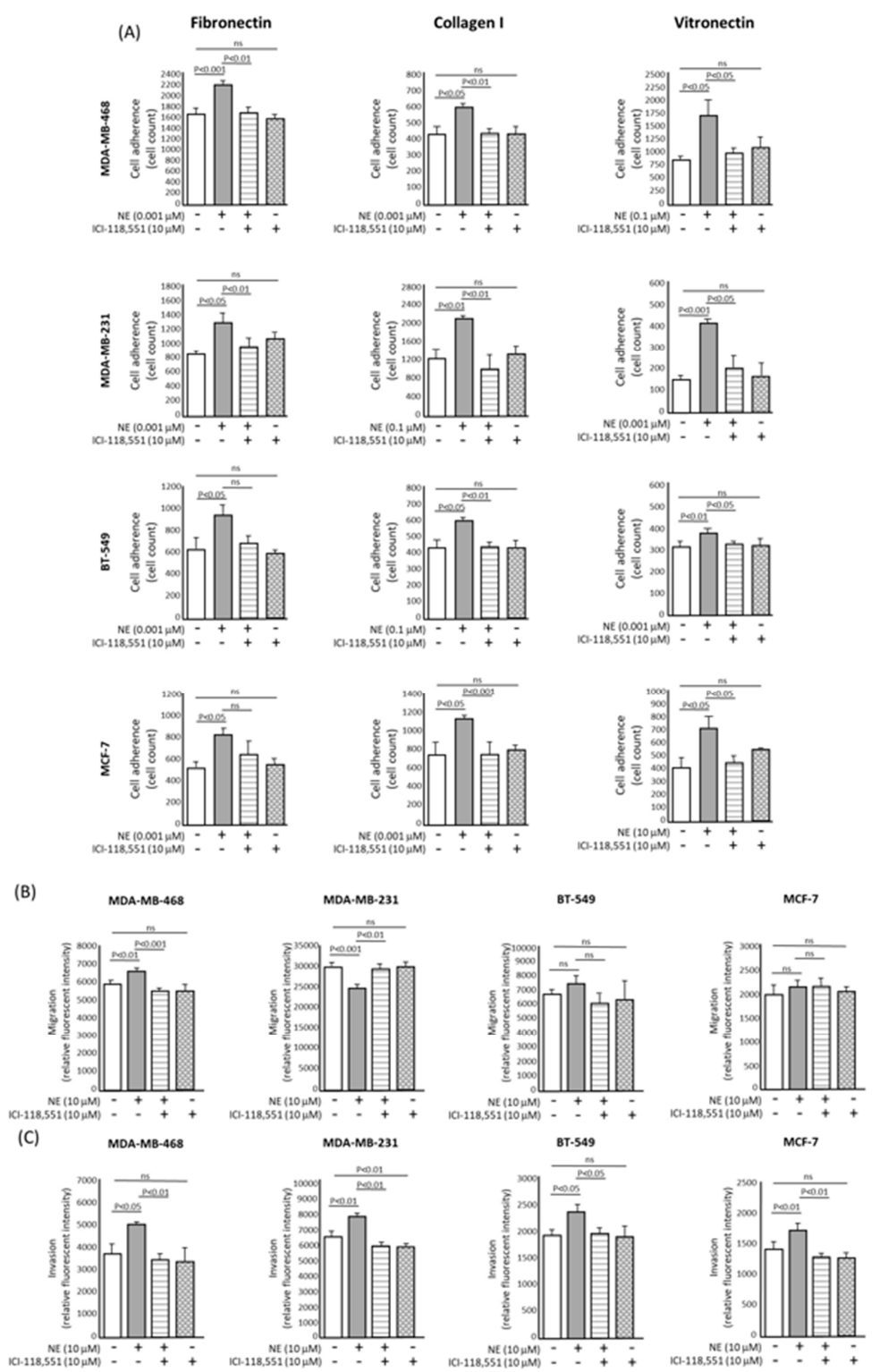

Figure 2. Effect of norepinephrine and the selective $\beta 2$-adrenoceptor antagonist ICI-118,551 on breast cancer cell adhesion, migration and invasion in vitro. (A) $\beta 2$-adrenoceptor blockade using ICI-118,551 inhibits norepinephrine-induced adhesion of breast cancer cells to fibronectin and collagen I in vitro. Quantitative analysis of the number of cells adhered to wells coated with $10 \mu \mathrm{g} / \mathrm{mL}$ of fibronectin, collagen I or vitronectin after $3 \mathrm{~h}$ of incubation. Simultaneous treatment with norepinephrine and the selective antagonist ICI-118,551 compound reduced the adhesion in all four cell lines grown on collagen I and vitronectin coated surfaces $(p<0.05)$. Only the basal-type MDA-MB-468 and MDA-MB-231 cell lines showed a reduction in cell adhesion when grown on fibronectin $(p<0.01)$. (B) Quantitative analysis of the influence of ICI-118,551 treatment on the transwell migration of the breast cancer cell lines. Norepinephrine challenge caused a significant increase in the migration of MDA-MB-468 cells $(p<0.05)$ and this increase was completely reversed by the concomitant administration of ICI-118,551 antagonist $(p<0.05)$. (C) Quantitative analysis of the influence of ICI-118,551 treatment on the invasion of the breast cancer cell line through a basement membrane epithelium (BME) coated membrane. Treatment with the ICI-118,551 antagonist significantly decreased the invasive capacity of MDA-MB-468, MDA-MB-231 and MCF-7 cell lines following norepinephrine challenge $(p<0.05)$. All assays were performed in triplicate $(n=3)$. Results shown are the mean \pm standard deviation. Statistical analysis was performed using a one-way ANOVA (analysis of variance) test (Dunnett's multiple comparison test). 


\subsection{Protein Expression Changes in MDA-MB-468 and MDA-MB-231 Cells}

To further investigate the potential role of the ADR $\beta 2$ in breast cancer cell migration, we performed mass spectrometry analyses of protein extracts taken from the lysate and media (secretome) of MDA-MB-468 and MDA-MB-231 cells treated with norepinephrine, isoproterenol and ICI-118,551 (Supplementary Materials Table S4). These cell lines were chosen for the following reasons: increased levels of ADR $\beta 2$ mRNA expression, the cells displayed opposing effects following norepinephrine stimulation and the cell lines were derived from the triple negative phenotype, which is of importance for developing new potential treatment regimens or repurposing current therapeutics. Differentially expressed proteins for MDA-MB-468 and MDA-MB-231 cells secretome and lysate are shown in Tables 1 and 2. One thousand one hundred and sixty eight (MDA-MB-468 secretome), 2715 (MDA-MB-468 lysate), 2635 (MDA-MB-231 secretome) and 3117 (MDA-MB-231 lysate) proteins were quantified by SWATH-MS (Sequential Window Acquisition of All Theoretical Mass Spectra - Mass Spectrometry) and processed using OneOmics (Sciex, Framingham, MA, USA). The analysis revealed several differentially expressed proteins within each cell line; however, the similarity between the cell lines in terms of shared proteins was minimal with the following shared proteins only observed in the norepinephrine and ICI-118,551 treated cells; H4 (P02805) and TSP (P07996). This is not unsurprising given the differences in magnitude of response following stimulation of these cells with ADR agonists/antagonists.

Table 1. Differentially expressed proteins identified using SWATH (Sequential Window Acquisition of All Theoretical Mass Spectra) MS (mass spectrometry) analysis of MDA-MB-468 cell lysate and secretome following adrenoceptor agonism/antagonism.

\begin{tabular}{|c|c|c|c|c|c|c|}
\hline Treatment (vs UT) & \multicolumn{3}{|c|}{ Lysate } & \multicolumn{3}{|c|}{ Secretome } \\
\hline \multirow{10}{*}{ NE } & LYPD3 & O95274 & 2.235 & IF5A1 & P63241 & 2.181 \\
\hline & NDRG1 & Q92597 & 1.021 & LYPD3 & O95274 & 1.577 \\
\hline & CASPE & P31944 & 1.015 & H4 & P62805 & 1.489 \\
\hline & AATM & P10809 & -1.010 & STC1 & P52823 & 1.077 \\
\hline & HINT2 & Q9BX68 & -1.206 & & & \\
\hline & MDHM & P40926 & -1.315 & & & \\
\hline & ECH1 & Q13011 & -1.431 & & & \\
\hline & H14 & P10412 & -1.515 & & & \\
\hline & ODO4 & P36957 & -1.520 & & & \\
\hline & $\mathrm{H} 12$ & P16403 & -1.574 & & & \\
\hline \multirow[t]{4}{*}{ ISO } & & & & ANXA1 & P04083 & 1.065 \\
\hline & & & & CTGF & P29279 & -1.151 \\
\hline & & & & UBA3 & Q8TBC4 & -1.995 \\
\hline & & & & LAMC1 & P11047 & -3.499 \\
\hline \multirow{6}{*}{ ICI 118,551} & S10-A7 & P31151 & 1.271 & NDKA & P15531 & 3.784 \\
\hline & & & & IF5A1 & P63241 & 2.252 \\
\hline & & & & S10A6 & P06703 & 1.651 \\
\hline & & & & ANXA2 & P07355 & 1.311 \\
\hline & & & & DPY30 & Q9C005 & 1.286 \\
\hline & & & & EDF1 & O60869 & -2.432 \\
\hline
\end{tabular}


Table 1. Cont.

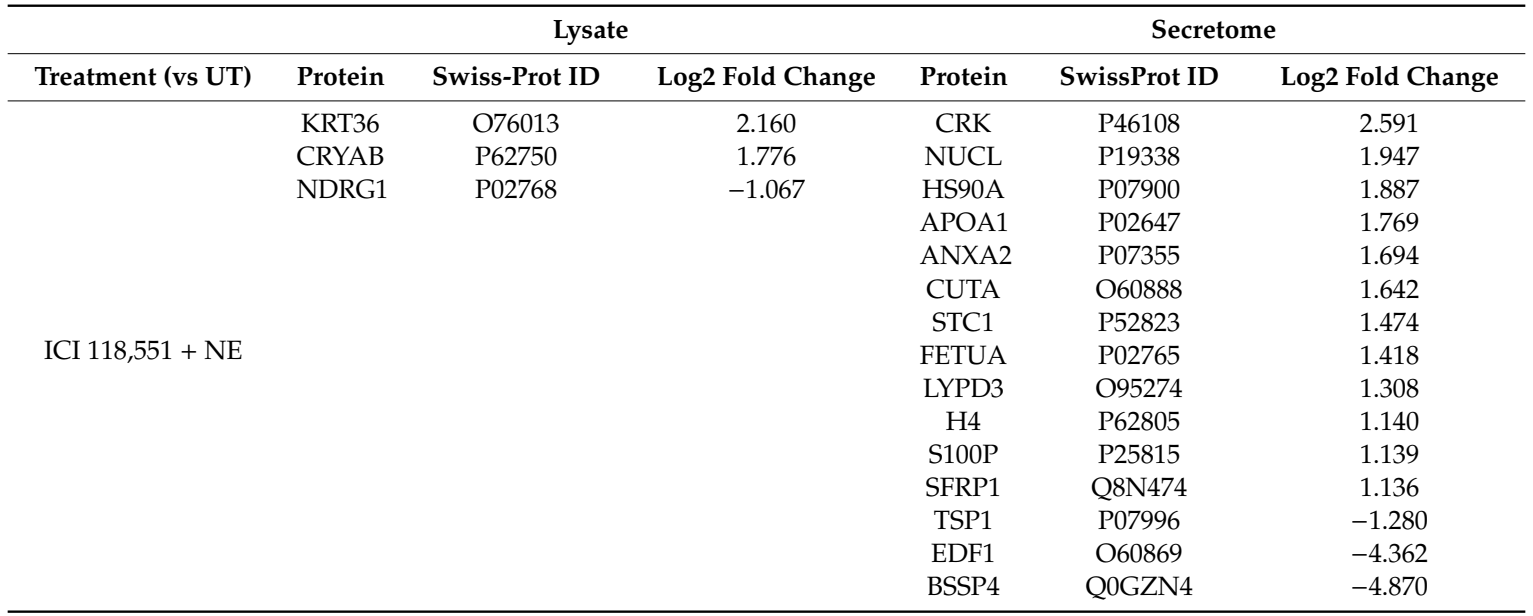

Log2 fold change represents the increase/decrease in protein expression relative to untreated samples (UT). Proteins with a Log2 fold change of $<1.0$ or $>1.0$ and OneOmics confidence of $\geq 60 \%$ are shown. Proteins with single peptides are excluded. Data is from six biological replicates. NE—norepinephrine, ISO-isoproterenol, UT—untreated.

Table 2. Differentially expressed proteins identified using SWATH MS analysis of MDA-MB-231 cell lysate and secretome following adrenoceptor agonism/antagonism.

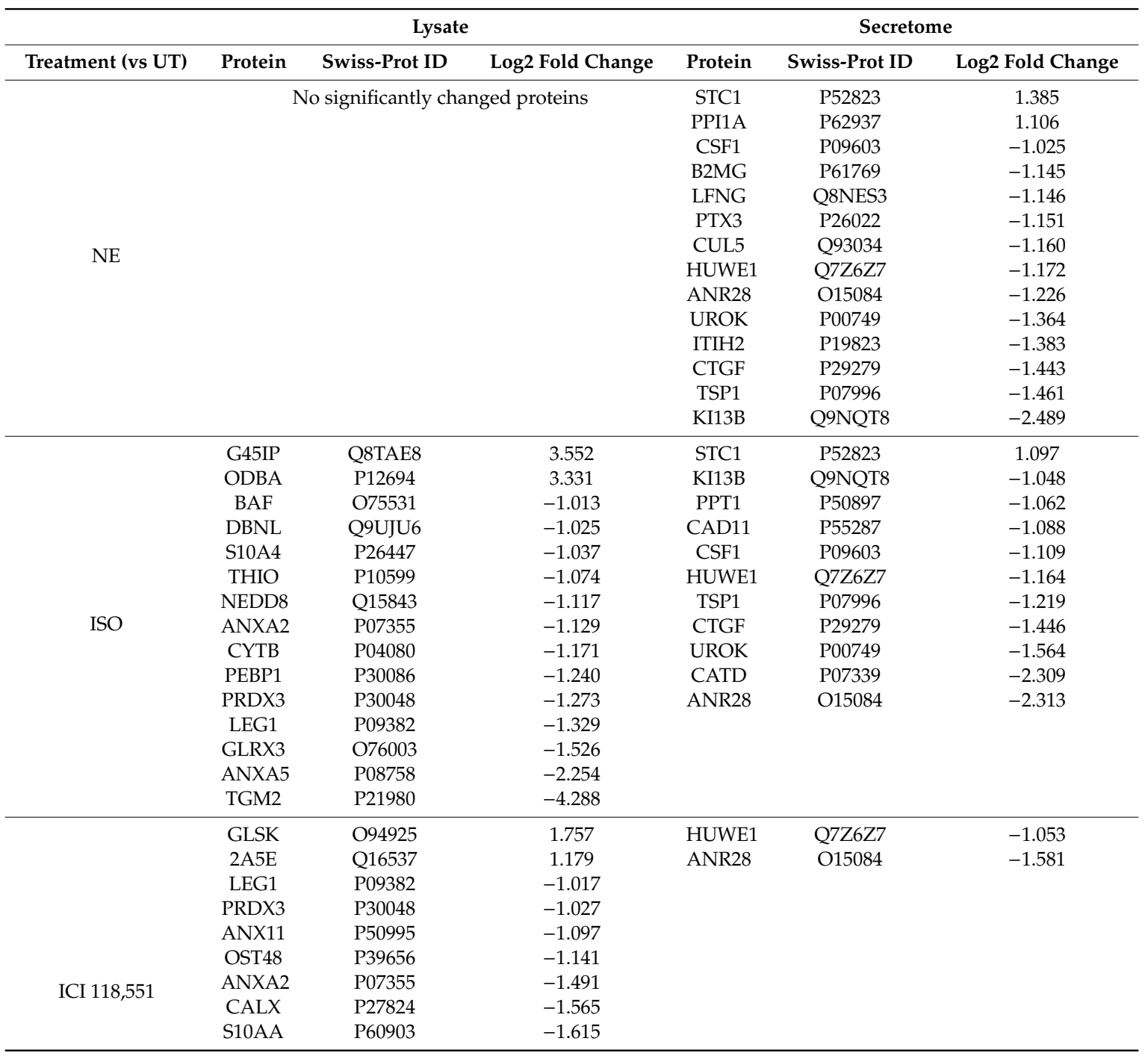


Table 2. Cont.

\begin{tabular}{llccccc}
\hline & \multicolumn{2}{c}{ Lysate } & \multicolumn{2}{c}{ Secretome } \\
\hline Treatment (vs UT) & Protein & Swiss-Prot ID & Log2 Fold Change & Protein & Swiss-Prot ID & Log2 Fold Change \\
\hline & ANXA4 & P09525 & -1.670 & & & \\
& PEBP1 & P30086 & -1.788 & & & \\
& GALT2 & Q10471 & -1.927 & & & \\
& DNJA2 & O60884 & -2.297 & & & \\
& CP1B1 & Q16678 & -3.311 & & & -1.019 \\
& ODBA & P12694 & 3.341 & RLA2 & P62805 & -1.071 \\
& S10AA & P60903 & -1.077 & CUL5 & Q93034 & -1.078 \\
& ANX11 & P50995 & -1.223 & H4 & P62805 & -1.079 \\
& ANXA2 & P07355 & -1.460 & TCRG1 & O14776 & -1.175 \\
& ANXA4 & P09525 & -1.779 & BGH3 & Q15582 & -1.180 \\
& CP013 & Q96S19 & -2.699 & PPT1 & P50897 & -1.230 \\
& & & CYTS & P01037 & -1.298 \\
& & & TSP1 & P07996 & -1.345 \\
& & & CYTN & P01037 & -1.454 \\
& & & SRPX & P78539 & -1.509 \\
& & & HUWE1 & Q7Z6Z7 & -1.510 \\
& & & ITIH2 & P19823 & -1.930 \\
& & & FINC & P02751 & -2.080 \\
\hline
\end{tabular}

Log2 fold change represents the increase/decrease in protein expression relative to untreated samples (UT). Proteins with a Log2 fold change of $<1.0$ or $>1.0$ and OneOmics confidence of $\geq 60 \%$ are shown. Proteins with single peptides are excluded. Data is from six biological replicates. NE—norepinephrine, ISO-isoproterenol, UT—untreated.

Of significant interest was one protein, LYPD3, whose increased levels were found in the lysate (2.235 fold change) and secretome (1.577 fold change) of MDA-MB-468 cells following norepinephrine treatment (Table 1, Supplementary Materials Figure S4A) and in the lysate of MDA-MB-468 isoproterenol treated cells (Table 1 and Supplementary Materials Figure S4B). Concomitant treatment with norepinephrine and ICI-118,551 produced a smaller increase in LYPD3 levels in the secretome of MDA-MB-468 (1.308 fold change) cells compared to norepinephrine stimulation alone (Table 1).

\subsection{Increased LYPD3 Protein Is Exclusively Expressed in Primary and Metastatic Breast Cancer}

The association between LYPD3 protein expression with tumour malignancy, patient age, tumour grade and stage, TNM, oestrogen receptor and HER2 status are shown in Table 3. LYPD3 protein staining was localised in the cytoplasm of breast adenocarcinoma cells, with occasional intense staining in cellular membranes (Figure 3A). LYPD3 protein expression was exclusively localised in primary (13.1\% positive) and metastatic (17\% positive) breast adenocarcinoma tissues, with no difference between the two groups $(p=0.171)$. LYPD3 protein was not localised in adjacent normal breast tissue. In further analyses, the malignant and metastatic cases were combined and compared to adjacent normal breast cases. LYPD3 expression was decreased in low stage breast cancer lesions (stage I) $(p=0.028)$ and was observed in low grade lesions, but the latter did not reach significance. There was no significant association between LYPD3 and age, oestrogen receptor or HER2 status. 
Table 3. Clinical details of cases histologically assessed for LYPD3 protein expression was compared in malignant (primary and metastatic) breast adenocarcinoma tissue.

\begin{tabular}{|c|c|c|c|}
\hline \multicolumn{4}{|c|}{ LYPD3 Score } \\
\hline & Negative & Positive & Chi Square ( $p$-Value) \\
\hline \multicolumn{4}{|l|}{ Age } \\
\hline$<40$ & $55(91.7 \%)$ & $5(8.3 \%)$ & $2.885(0.236)$ \\
\hline $40-59$ & $179(84.8 \%)$ & $32(15.2 \%)$ & \\
\hline$>60$ & $43(91.5 \%)$ & $4(8.5 \%)$ & \\
\hline \multicolumn{4}{|l|}{ Tumour Grade } \\
\hline 1 & $39(14.1 \%)$ & $2(4.9 \%)$ & $10.034(0.074)$ \\
\hline $1-2$ & $4(1.4 \%)$ & $1(2.4 \%)$ & \\
\hline 2 & $105(37.9 \%)$ & $19(46.3 \%)$ & \\
\hline $2-3$ & $0(0)$ & $1(2.4 \%)$ & \\
\hline 3 & $64(23.1 \%)$ & $9(22 \%)$ & \\
\hline \multicolumn{4}{|l|}{ Tumour stage } \\
\hline I & $18(6.5 \%)$ & $2(4.9 \%)$ & $15.712(\mathbf{0 . 0 2 8})$ \\
\hline IIA & $102(36.8 \%)$ & $8(19.5 \%)$ & \\
\hline IIB & $32(11.6 \%)$ & $4(9.8 \%)$ & \\
\hline IIIA & $5(1.8 \%)$ & $3(7.3 \%)$ & \\
\hline IIIB & $19(6.9 \%)$ & $3(7.3 \%)$ & \\
\hline IV & $5(1.8 \%)$ & $1(2.4 \%)$ & \\
\hline \multicolumn{4}{|l|}{ Oestrogen receptor status } \\
\hline Negative & $137(69.2 \%)$ & $16(76.2 \%)$ & $0.442(0.506)$ \\
\hline Positive & $61(30.8 \%)$ & $5(23.8 \%)$ & \\
\hline \multicolumn{4}{|l|}{ HER2 status } \\
\hline Negative & $162(81.4 \%)$ & $14(66.7 \%)$ & $2.580(0.108)$ \\
\hline Positive & $37(18.6 \%)$ & $7(33.3 \%)$ & \\
\hline \multicolumn{4}{|l|}{ Tissue pathology status } \\
\hline Malignant primary breast tumour & $219(86.9 \%)$ & $33(13.1 \%)$ & $3.535(0.171)$ \\
\hline Metastasis & $39(83 \%)$ & $8(17 \%)$ & \\
\hline Adjacent normal breast tissue & $19(100 \%)$ & $0(0 \%)$ & \\
\hline
\end{tabular}



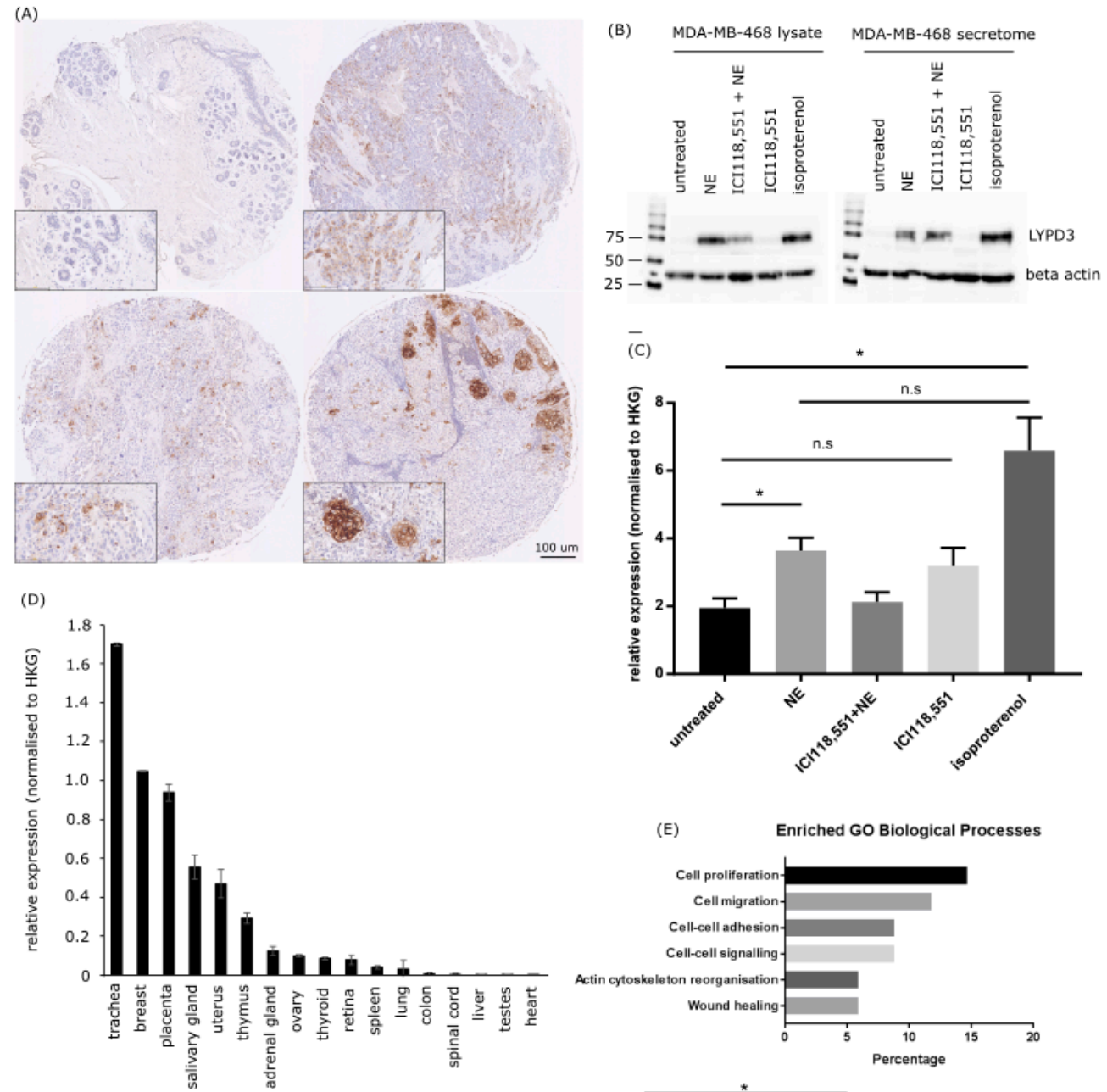

(F)
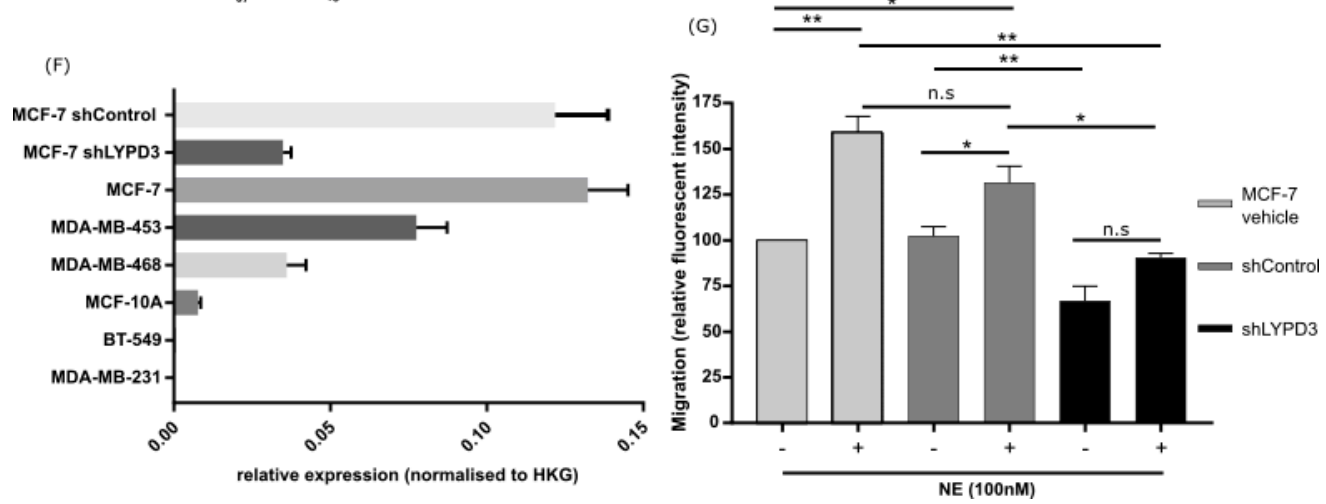

Figure 3. LYPD3 expression in breast patient TMAs (tumour micro arrays), breast cancer cell lines and a normal tissue RNA panel and the effects of LYPD3 gene knockdown. (A) IHC (immunohistochemistry) staining of LYPD3 in (top left) normal breast, (top right) invasive ductal carcinoma (TN, grade 3, stage I), (bottom left) invasive ductal carcinoma (TN, grade 3, stage IIA), (bottom right) lymph nodes metastases from patients with invasive ductal carcinoma. (B) Western blot of LYPD3 expression in $50 \mu \mathrm{g}$ protein extracted from the cell lysate (left hand panel) or secretome (right hand panel) of MDA-MB-468 cells following treatment demonstrated an upregulation of LYPD3 protein following treatment with norepinephrine or isoproterenol alone and also following concomitant treatment with ICI118,551. (C) LYPD3 gene expression level in MDA-MB-468 cells following treatment demonstrates a significant upregulation of LYPD3 in norepinephrine and isoproterenol stimulated MDA-MB-468 cells. Results shown are the mean \pm standard deviation. Statistical analysis was performed using an un-paired Student's T-test. ${ }^{*} p<0.05,{ }^{* *} p<0.01$. (D) LYPD3 gene expression levels (relative to the house keeping 
gene-HKG) in a panel of normal human tissues illustrates low levels of expression in the majority of essential tissues tested (lung, spinal cord, liver, heart) (E) Enriched GO biological processes (as defined by David annotation tool) of differentially expressed proteins identified via the mass spectrometry analysis within the top 50 strongest interactions as defined by network inference analysis. The normalised protein expression values of each identified protein (cut-off above $50 \%$ confidence) within the untreated and norepinephrine treated cohorts (both lysate and secretome) were subjected to a network inference analysis. In the network, the 50 strongest interactions (based on their absolute values) between any of the proteins (defined by their strength of interaction) were selected and submitted to the David annotation tool and as observed the top pathways identified were those associated with cell proliferation, migration, adhesion and cell signalling. (F) LYPD3 gene expression levels in a panel of breast cell lines (relative to the house keeping gene-HKG) showing that the more mesenchymal cell lines (MDA-MB-231 and BT-549) express negligible levels of LYPD3 compared to the more epithelial cell lines (MDA-MB-468, MDA-MB-453) with MCF-7 cells demonstrating the highest level of expression. Subsequently, the level of LYPD3 expression in MCF-7 cells could be reduced by the incorporation of LYPD3 specific shRNA to $26.4 \%$ of its original levels. (G) The effects of LYPD3 gene knockdown on the migration of MCF-7 breast cancer cells showed a significant reduction in the migration of MCF-7 vehicle cells following norepinephrine stimulation $(p=0.0065)$. There was also a reduction in the migration of MCF-7 cells following LYPD3 shRNA knockdown compared to shControl $(p=0.0054)$. All assays were performed in triplicate $(n=3)$. Results shown are the mean \pm standard deviation. Statistical analysis was performed using an ANOVA test (Dunnett's multiple comparison test). ${ }^{*} p<0.05,{ }^{* *} p<0.01$.

\subsection{LYPD3 Knockdown Significantly Reduces the Migration of MCF-7 Cells In Vitro}

The levels of LYPD3 in the lysate and secretome of MDA-MB-468 cells was measured following adrenergic receptor stimulation and subsequent blocking with a $\beta 2$-specific antagonist (Figure 3B). LYPD3 protein expression was increased in norepinephrine $(p=0.0375)$ and isoproterenol $(p=0.0234)$ stimulated cells with a subsequent decrease observed following treatment with an ADR $\beta 2$ antagonist (Figure 3C). LYPD3 mRNA expression levels were low in normal tissues (Figure 3D) and when the significantly associated proteins identified in the mass spectrometry analysis of MDA-MB-468 cell lysates and secretome were subjected to network inference and subsequently altered pathways were identified via the David annotation tool, it could be observed, as expected, that the most significant pathways were associated with cell proliferation, migration and adhesion (Figure 3E and Supplementary Materials Table S1A). The expression of LYPD3 in breast cancer cell lines varied with MCF-7 cells expressing the highest levels. This expression could be knocked down to $26.4 \%$ of its basal level using a LYPD3 specific shRNA (Figure 3F). MCF-7 cells were transfected with vehicle alone, shControl or shLYPD3 and stimulated with or without norepinephrine for $24 \mathrm{~h}$ to induce cell migration. Following norepinephrine treatment, cell migration significantly increased in MCF-7 vehicle cells $(p=0.0072)$ and shControl (0.0268) but not in the shLYPD3. The increase in migration observed in MCF-7 vehicle cells is more than originally observed (Figure 2B) and this could be due to two factors; a lower concentration of norepinephrine was used to stimulate the cells $(100 \mathrm{nM}$ vs. $10 \mu \mathrm{M})$ and the cells used in the knockdown studies were of a slightly lower passage number (passage $5 \mathrm{vs.} \mathrm{passage} 8$ ). The difference in cell migration observed between the norepinephrine stimulated vehicle only cells and the shControl cells was not statistically significant $(p=0.1142)$.

In addition, shLYPD3 knockdown of norepinephrine stimulated MCF-7 cells caused a significant decrease in migration compared to vehicle alone cells $(p=0.0065)$ and shControl cells $(p=0.0016)$. Furthermore, in unstimulated cells there was a significant decrease in cell migration of shLYPD3 compared to shControl (0.0054) and vehicle treated cells (0.0188) (Figure 3G and Supplementary Materials Figure S5). These results indicate that cell migration may be influenced by LYPD3 acting via $\mathrm{ABR} \beta$ signalling pathways. 
2.6. Elevated Levels of LYPD3 mRNA Are Present in Malignant Disease Compared to Their Non-Malignant Counterpart in Several Cancers

Although previous studies have shown that LYPD3 is expressed in malignant tissues [20-22], a comprehensive screen of recent mRNA expression data has, to the best of our knowledge, not been performed. In our analysis we screened all cancers for the comparative mRNA expression levels between malignant and normal counterparts using GEPIA [23]. Our analysis revealed that in seven cancers (breast, cervical squamous cell carcinoma and endocervical adenocarcinoma, lung adenocarcinoma, lung squamous cell carcinoma, pancreatic adenocarcinoma, testicular germ cell tumours and thymoma) there is a significant $(p<0.001)$ over-expression of LYPD3 in the malignant tissue versus the normal counterpart (Figure 4). This suggests that LYPD3 could be a potential therapeutic target in multiple different cancers, and is not solely restricted to breast, oesophageal, pancreatic and lung carcinomas.

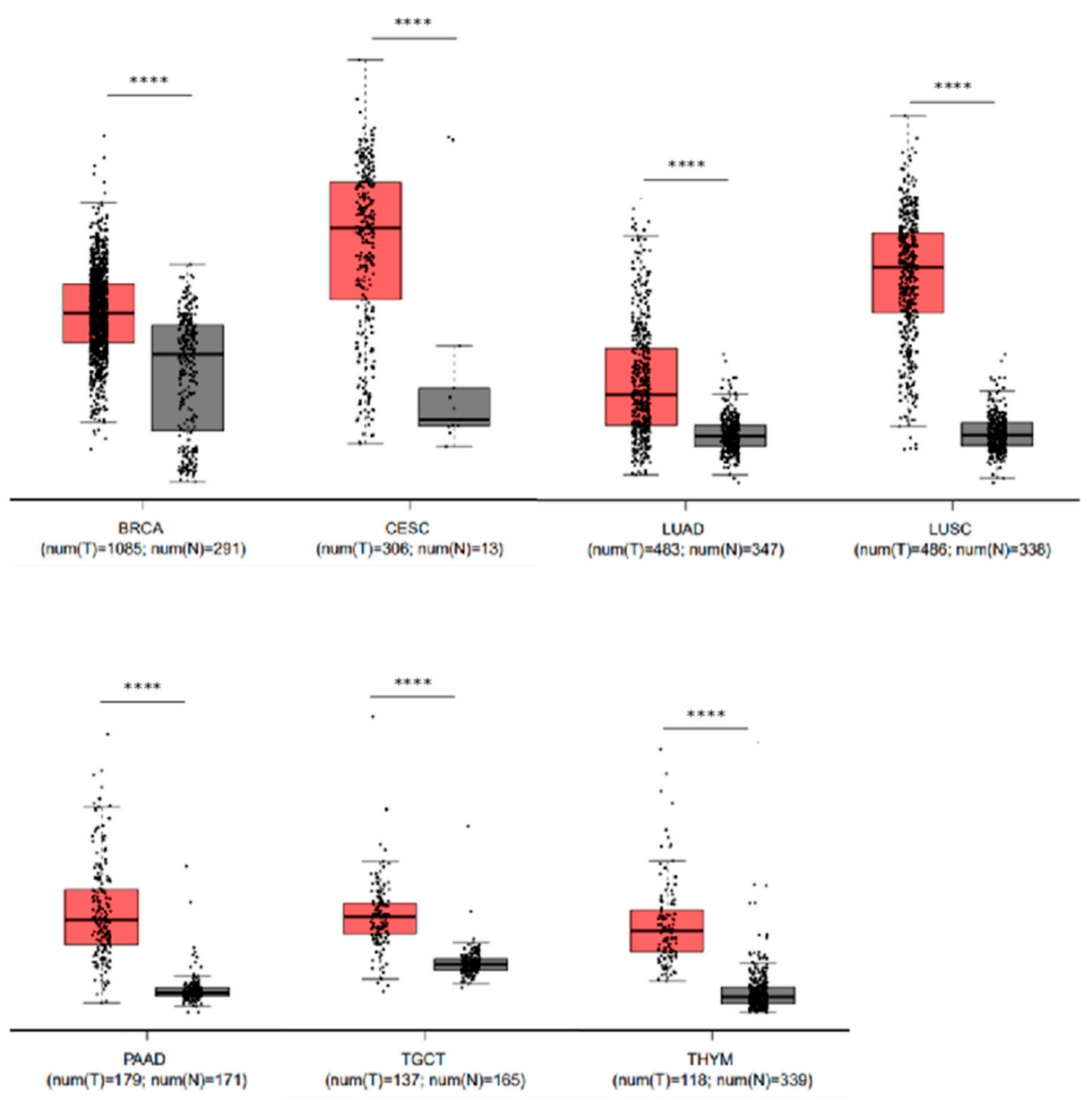

Figure 4. LYPD3 mRNA expression is significantly $(p<0.001)$ upregulated in malignant cancer $(\mathrm{T})$ versus the normal tissue $(\mathrm{N})$ counterpart. Box and whisker plots illustrating the mRNA expression levels of LYPD3 in the following cancer versus normal tissue: BRCA—breast cancer, CESC - cervical squamous cell carcinoma and endocervical adenocarcinoma, LUAD-lung adenocarcinoma, LUSC_lung squamous cell carcinoma, PAAD—pancreatic adenocarcinoma, TGCT—-testicular germ cell tumours and THYM-thymoma. Cancer are coloured red whilst normal are coloured grey. Each point represents an individual data point and the number of data points in each analysis is stated under the $x$-axis. The $\log 2$ fold change cut-off is 1 and differential analysis is by one-way ANOVA, using disease state as the variable for calculating differential expression. 


\section{Discussion}

Early population studies reported an association between beta-blocker use and survival in patients with breast cancer [10-12]. The proposed physiological mechanism involved inhibition of $\beta$-adrenoceptor-activated cancer cell signalling pathways [8,19,23-31], resulting in a reduction of metastasis $[9,32,33]$. Specific mediators implicated downstream of this process have, to our knowledge, not been identified. Furthermore, the influence of adrenergic ligands on cell migration in vitro have been controversial [7-9]. We found that two of the non-stimulated triple-negative basal-type breast cancer models, MDA-MB-231 and MDA-MB-468, showed significantly raised levels of $\beta 2$-adrenoceptor gene and protein expression compared to the oestrogen responsive cell line. Although a challenge with a non-selective ADR $\beta 2$ agonist confirmed functional adrenoceptors in all four cancer cell lines, the strongest response was seen in MDA-MB-231 and MDA-MB-468, as evidenced by increased cAMP.

Although laboratory evidence supporting a clinical use for the beta-blocker propranolol in breast oncology is strong, it has not been universal, in that propranolol is reported by some to increase the proliferation of basal-type MDA-MB-231 breast cancer cells [34-37], but not by others [19,38]. We did not demonstrate a significant increase in survival in the breast cancer cells in response to a selective $\beta 2$-adrenoceptor antagonist (ICI-118,551). A recent orthotopic mouse model of basal-type MDA-MB-231 breast cancer concurred that propranolol does not reduce primary tumour growth, but instead reduces the number and size of metastatic tumours [9]. In summary, beta-blockers appear not to be cytotoxic per se, but when combined with paclitaxel chemotherapy they appear to enhance its effectiveness, as demonstrated in a mouse basal-type (MDA-MB-231) breast cancer model [27].

Herein, the association between ADR $\beta 2$ expression and key characteristics involved in metastasis was assessed in four breast cancer models, including cell migration, adhesion and invasion. Migration assays confirmed that the agonist norepinephrine increased the migration of MDA-MB-468, BT-549 and MCF-7 cells, which was abrogated by the ADR $\beta 2$ antagonist ICI-118,551. In contrast, norepinephrine reduced the migration of MDA-MB-231 cells, and ICI-118,551 increased their migration, as has been reported by Carrie and Sebti [19]. However, when grown on collagen-1 or fibronectin protein-coated plastic or synthetic membranes coated with basement membrane protein, MDA-MB-231 cells showed a similar migratory behaviour to the other models (data not shown), thereby supporting the findings of others [8,39,40]. In addition, two basal-type cell lines (MDA-MB-231, MDA-MB-468) and the ER-positive MCF-7 cells exhibited increased norepinephrine-induced invasive behaviour that was abrogated by the ICI-118,551 antagonist. These findings suggest ADR $\beta 2$ mediated cellular pathways could be influenced by cell adhesion molecules [41], and may explain anomalous behaviour reported for the MDA-MB-231 cancer model when grown on different surfaces. This is further supported by the identification of proteins involved in cell adhesion, proliferation and migration following a mass spectrometry analysis of MDA-MB-468 cell lysates and secretome after ADR $\beta 2$ agonism/antagonism. The differences in migration observed between the MDA-MB-468 and MDA-MB-231 cells could, in part, be explained by differences in signalling arising because MDA-MB-468 cells are of epithelial origin (i.e., pre-epithelial-mesenchymal transition EMT), whilst MDA-MB-231 cells possess a mesenchymal-like phenotype (post-EMT). In MDA-MB-468 cells, norepinephrine could be signalling to initiate the acquisition of a more motile cell phenotype that would allow the cancer cells to spread, whereas in the MDA-MB-231 cells the presence of norepinephrine in the tissue microenvironment would signal that there is a favourable environment present for the cancer cells to successfully colonise and establish a secondary tumour/metastatic lesion [42-45]. Literature also demonstrates that catecholamines can both protect cancer cells from apoptosis [33] as well as providing an advantageous environment whereby secondary tumours often become established at catecholamine-producing tissues such as the brain and adrenal glands [46]. Furthermore, we hypothesise that the opposing influence of adrenergic stimulation on cell migration of MDA-MB-468 and MDA-MB-231 cell lines could be linked to ADR heterodimerisation. Lavoie et al. showed that heterodimerisation of ADR $\beta 1$ and ADR $\beta 2$ prevented agonist-induced internalisation of ADR $\beta 2$ [47] and in our study we demonstrated that MDA-MB-468 cells expressed higher levels of the ADR $\beta 1$ 
receptor than MDA-MB-231 cells. Furthermore, pharmacological diversity could be introduced via heterodimerisation leading to differential desensitisation, changes in cell surface receptor expression and alterations to the functionality of ADR subtypes [48-53].

Clearly there are many conflicting results in the literature for the two-dimensional migration of MDA-MB-231 cells and its variants $[7,8,11,36,42]$. There are a number of plausible reasons behind the differing results observed between the reports in the literature; including, the differing passage numbers of cells, different sources of the cell lines, the different methods and conditions used in performing the assays as well as time spans of the experiments. In addition, other reasons could be: (i) differing levels of $\beta 2$-adrenoceptor signalling capacity in relation to the differing levels of $\beta 2$ adrenoceptor expression and (ii) differing dose-dependent downstream signalling behaviours of the cell lines, including cAMP signalling. Not unsurprisingly, when the GO biological processes associated with the treatment of MDA-MB-231 cells with norepinephrine was investigated in our proteomic study, a number of genes associated with the following pathways were identified; proliferation, migration, adhesion, negative regulation of the apoptotic process and membrane organisation (Supplementary Materials Table S1B). Furthermore, Madden et al. has also shown that MDA-MB-231 cells can possess an impaired cAMP signalling, with cAMP levels remaining high after stimulation by forskolin, which could have profound effects and could possibly be a reason for the observed differences with this cell line [28]. In addition, Pon et al. demonstrated that the parental MDA-MB-231 cell line does not possess the feedforward $\mathrm{Ca}^{2+} / \mathrm{cAMP}$ loop and therefore has low levels of cAMP production and a delayed response to stress [25].

Furthermore, Kim et al. and Choy et al. used different variants of the parental MDA-MB-231 cell line, which could have profound influence on the in vitro behaviour of the cells in response to external stimulants such as isoproterenol [8,42]. Indeed, Pon et al. showed that the highly-metastatic variant of the MDA-MB-231 cell line, MDA-MB-231 ${ }^{\mathrm{HM}}$ are more responsive to $\beta$-adrenergic signalling than the parental MDA-MB-231 cell line and this is reflected in the limited cAMP signalling observed in the parental MDA-MB-231 cells compared to the high metastatic MDA-MB-231 ${ }^{\mathrm{HM}}$ variant [25]. The two-dimensional migratory activity of MDA-MB-231 cells in response to isoproterenol has also been assessed on different extracellular matrix (ECM) protein surfaces where again, opposing effects were observed, even on the same surface, adding to the conflicting results of this cell line in the literature [26,43].

We report that the strongest association between high ADR $\beta 2$ expression and cell behaviours indicative of tumour aggression exists in two triple-negative basal-type breast cancer models (MDA-MB-231, MDA-MB-468). Moreover, we have identified distinctly different protein profiles between the two models in response to ADR $\beta 2$ activation, with differential expression of the pro-metastasis protein LYPD3 observed in MDA-MB-468 cells following ADR stimulation and/or ADR 32 antagonism/inverse agonism. Stimulation of MDA-MB-468 cells with norepinephrine or isoproterenol increased the levels of LYPD3 within the cell lysate, and was also secreted in the media. Treatment with the antagonist ICI-118,551 reduced LYPD3 expression to a lower level than that observed following norepinephrine/isoproterenol stimulation both in the lysate and secreted into the media. LYPD3 is a glycosyl-phosphatidyl-inositol (GPI) anchored glycoprotein whose expression, we have confirmed, is highly restricted in normal tissues [54,55]. Studies have also demonstrated a strong association with a poor prognosis $[20,22,56-58]$ and even though its expression has been observed in breast cancer both in this study and in other published studies [21,59], its influence on tumourigenesis is yet to be elucidated although our patient tumour microarray (TMA) data suggests that LYPD3 is exclusively expressed in primary breast cancer and metastatic cases, with no expression observed in normal breast tissue. Furthermore, our in silico analysis has revealed that LYPD3 may be a therapeutic target in multiple cancer types, some of which have not been reported in the literature (testicular germ cell tumours and thymoma). Interestingly, upregulation of LYPD3 has been observed following cellular stress [60], however, this is the first study showing that treatment of breast cancer cells with the endogenous stress hormone norepinephrine, can also lead to elevated LYPD3 levels. 
In MDA-MB-468 cells, treatment with the non-selective ADR $\beta$ agonist, isoproterenol, unregulated LYPD3, whereas ICI-118,551, a selective ADR $\beta 2$ antagonist, reduced norepinephrine-induced LYPD3 expression and, when administered alone, reduced LYPD3 levels to that below the basal expression. This would suggest, through a mechanism yet to be elucidated, that LYPD3 is regulated via the ADR 32 signalling pathway. In oesophageal cancer, LYPD3 is regulated via CREB (cAMP response element binding protein) transcription co-activator signalling [61], and therefore, it is postulated that norepinephrine regulates LYPD3 through an ADR $32 / \mathrm{CAMP} / \mathrm{PKA} / \mathrm{CREB} / \mathrm{LYPD} 3$ effector pathway [45]. In this pathway a conformational change in ADR $\beta 2$ would be induced following binding of norepinephrine, mediating activation of the $G_{s} \alpha$ protein subunit. Following activation, $G_{s} \alpha$ can then stimulate the adenylyl cyclase-induced conversion of adenosine triphosphate (ATP) into cAMP, resulting in protein kinase A (PKA) activation. Downstream this would enable phosphorylation of CREB via PKA, thereby inducing the transcriptional upregulation of LYPD3, and hence, increasing cell migration $[45,61]$. In this study we have demonstrated the importance of LYPD3 in breast cancer cell migration by successfully knocking down the expression of LYPD3 using LYPD3-specific shRNA. We found that cell migration, measured using transwell migration assays, was significantly reduced following shLYPD3 compared to shControl.

In the secretome of MDA-MB-468 cells, increased levels of LYPD3 and decreased levels of LAMC1 (Laminin Subunit Gamma 1) were also observed following treatment with norepinephrine and isoproterenol. This is an interesting observation because it is thought that LYPD3 can be cleaved from the cell surface by ADAM Metallopeptidase Domain (ADAM)-10 and -17 and this shedding can be induced by hypoxia [62]. To speculate, once LYPD3 has been shed, it may still be able to bind laminin, via associating with the $\alpha 6 \beta 4$ integrin and matrix metallopeptidase-14 (MMP-14) and contribute towards its fragmentation and the observed decrease in LAMC1 that we observed in our proteomic analysis $[60,63]$. Alternatively, like its structural homologue urokinase-type plasminogen activator receptor (uPAR), shed-LYPD3 could function as a chemoattractant [64].

In MDA-MB-231 cells, LYPD3 was not detected in the library of proteins generated from either the lysate or the secretome and this observation was confirmed by gene expression analysis of LYPD3 in a range of breast cell lines illustrating that MDA-MB-231 cells do not express LYPD3 at the mRNA level. LYPD3 was expressed at negligible levels in the BT-549, which is also a cell line of mesenchymal origin. Higher levels of expression of LYPD3 were observed in the epithelial-derived cell lines suggesting that LYPD3 expression may correlate with EMT. Furthermore, Harner-Foreman et al. published a spontaneous model of prostate cancer [65] and unpublished mass spectrometry proteomic profiling data from this study revealed that LYPD3 was downregulated post-EMT. This is further supported by observations made by Oshiro et al., where significant associations were made between LYPD3 and EMT in both colorectal cancer cell lines and in clinical samples [66].

\section{Materials and Methods}

\subsection{Cell Lines}

The following breast cancer cell lines were purchased from the American Tissue Culture Collection (ATCC): BT-549 (HTB-122 ${ }^{\mathrm{TM}}$ ), ductal carcinoma; MCF-7 (HTB-22 ${ }^{\mathrm{TM}}$ ), adenocarcinoma; MDA-MB-231 (HTB-26 $^{\mathrm{TM}}$ ), adenocarcinoma; MDA-MB-468 (HTB-132 ${ }^{\mathrm{TM}}$ ), adenocarcinoma (Atcc.org, 2013). Breast cancer cell lines were cultured in DMEM (Dulbecco's Modified Eagle Medium) (Lonza, Slough, UK) containing 10\% v/v FCS (foetal calf serum) (GE Healthcare Life Sciences, Buckinghamshire, UK). All cells were grown at $37^{\circ} \mathrm{C}$, in a humidified atmosphere with $5 \% v / v \mathrm{CO}_{2}$. After washing in PBS (phosphate-buffered saline), breast cancer cells were harvested using Trypsin and EDTA (ethylenediaminetetraacetic acid)l (Lonza, Slough, UK). 


\subsection{RNA Extraction, $c D N A$ Synthesis and $q R T-P C R$}

RNA was extracted using an RNeasy mini kit (QIAGEN, Manchester, UK), then quantified on a NanoDrop ${ }^{\mathrm{TM}} 8000$ Spectrophotometer. cDNA synthesis was performed using MMLV-reverse transcriptase (Promega, Southampton, UK) and oligo-dT primers (Promega, Southampton, UK). In brief, $1 \mu \mathrm{L}$ oligo(dT) 15 primer (Promega, Southampton, UK) was annealed to $2 \mu \mathrm{g}$ of RNA. After being denatured for $5 \mathrm{~min}$ at $70{ }^{\circ} \mathrm{C}$, a master mix solution was added, which contained: $0.7 \mu \mathrm{L}$ Recombinant RNasin ${ }^{\circledR}$ Ribonuclease Inhibitor (Promega, Southampton, UK); $1 \mu \mathrm{L}$ Moloney-Murine Leukemia Virus (M-MLV) reverse transcriptase (Promega, Southampton, UK); $5 \mu \mathrm{L}$ M-MLV $5 \times$ reaction buffer (Promega, Southampton, UK); $1 \mu \mathrm{L}$ Deoxynucleotide Triphosphate Solution Mix (Sigma, Dorset, UK) and $2.3 \mu \mathrm{L}$ nanopure water. The samples were incubated for $60 \mathrm{~min}$ at $37^{\circ} \mathrm{C}$ and then heated for $5 \mathrm{~min}$ at $95^{\circ} \mathrm{C}$. cDNA was then stored at $-20^{\circ} \mathrm{C}$.

Semi-quantitative real-time PCR was performed using SYBR ${ }^{\circledR}$ Green (Bio-Rad, Watford, UK) chemistry and gene-specific primers (MWG Eurofins, Ebersberg, Germany) (Supplementary Materials Table S2) on a Rotor-Gene 6000 real-time PCR cycler (QIAGEN, Manchester, UK). PCR reactions were performed in $0.1 \mathrm{~mL}$ strip tubes containing a $12.5 \mu \mathrm{L}$ mixture of: SYBR ${ }^{\circledR}$ Green (Bio-Rad, Watford, UK); nanopure water; gene-specific primers (MWG Eurofins, Ebersberg, Germany) at a concentration of $5 \mathrm{pmol}$; and either $0.5 \mu \mathrm{L}$ of cDNA or nanopure water (control). The following cycling conditions were used (35-40 cycles): initial $5 \mathrm{~min}$ at $95^{\circ} \mathrm{C}$ for enzyme activation, followed by denaturation at $95^{\circ} \mathrm{C}$ for $10 \mathrm{~s}$, annealing for $15 \mathrm{~s}$ at the primer-specific Tm (Supplementary Materials Table S2), and extension at $72{ }^{\circ} \mathrm{C}$ for $20 \mathrm{~s}$. Following each PCR the melt curves were examined prior to data analysis. Using the Rotor-Gene Q Software and a threshold of 0.08, each transcripts $\mathrm{Ct}$ (cycle threshold) value was determined in triplicate. The relative expression of each target gene was then semi-quantified using the $2^{-\Delta \Delta C T}$ method.

\subsection{Flow Cytometry}

Unconjugated antibodies were fluorescently labelled using Lightning-Link ${ }^{\circledR}$ (Innova Biosciences, Cambridge, UK), according to the manufacturer's protocol: ADR $\alpha 1 \mathrm{~B}$ antibody with PE-Cy7 ${ }^{\mathrm{TM}}$; ADR $\alpha 1 \mathrm{D}$ antibody with APC (Allophycocyanin) and $\beta 2$-adrenoceptor antibody with RPE (R-Phycoerythrin). Harvested cells $\left(1 \times 10^{5}\right)$ were washed, pelleted and re-suspended in medium. Cells were then treated with an Fc receptor blocking reagent (Miltenyi Biotec, Bergisch Gladbach, Germany) diluted in PBS $\left(10 \mathrm{~min}, 4^{\circ} \mathrm{C}\right)$. Cells were incubated in the dark $\left(30 \mathrm{~min}, 4^{\circ} \mathrm{C}\right)$ with conjugated ADR antibodies (at a pre-optimised concentration) (Supplementary Materials Table S3) and viable cells were identified using LIVE/DEAD ${ }^{\mathrm{TM}}$ fixable violet dead cell stain (Thermo Fisher Scientific, Leicester, UK). Cells (minimum 10,000) were analysed by flow cytometry (Beckman Coulter Gallios ${ }^{\mathrm{TM}}$, Kaluza ${ }^{\mathrm{TM}}$ software).

\section{4. cAMP Signalling}

Cells were treated with the non-selective $\beta$-agonist isoproterenol $(1 \mu \mathrm{M}, 10 \mathrm{~min})$ and cAMP production measured using the cAMP Parameter ${ }^{\mathrm{TM}}$ ELISA kit (R\&D Systems, Minneapolis, MN, USA). IBMX was incorporated to prevent cAMP degradation and phosphodiesterase activity on cAMP production.

\subsection{Cellular Survival}

Cells were seeded at 5000 cells/well in $100 \mu \mathrm{L}$ of advanced DMEM containing 2\% FCS and $4 \mathrm{mM}$ L-glutamine. The cells were incubated at $37^{\circ} \mathrm{C}, 5 \% \mathrm{CO}_{2}$ in a humidified atmosphere for $24 \mathrm{~h}$. After $24 \mathrm{~h}$ the media was carefully removed and the cells washed once with PBS. Fresh serum-free advanced DMEM was added to each well and the cells serum-starved for $24 \mathrm{~h}$. After $24 \mathrm{~h}$, the media was removed and the cells washed with PBS. $100 \mu \mathrm{L}$ of advanced DMEM containing 2\% FCS and $4 \mathrm{mM}$ L-glutamine was adding to the wells with or without the addition of ICI-118,551 ( $\beta 2$-ADR selective antagonist, Sigma, Dorset, UK) (concentration range $1 \mathrm{pM}-10 \mu \mathrm{M}$ ). Cells were treated with antagonists for $30 \mathrm{~min}$ 
prior to the addition of $10 \mu \mathrm{M}$ norepinephrine (Sigma, Dorset, UK) for $72 \mathrm{~h}$ at $37^{\circ} \mathrm{C}$ in a humidified atmosphere containing $5 \% \mathrm{CO}_{2}$. After $72 \mathrm{~h}, 100 \mu \mathrm{L}$ of $2 \times$ detection reagent was added to each well and the plate incubated for $60 \mathrm{~min}$. The plate was then read using a Tecan Ultra fluorescent plate reader (Tecan Ultra, Mannedorf, Switzerland; excitation $485 \mathrm{~nm}$, emission $535 \mathrm{~nm}$ ).

\subsection{Adhesion Assays}

Cells were resuspended in $10 \mathrm{~mL}$ of serum-free media at 200,000 cells/mL in a falcon tube and were incubated for $30 \mathrm{~min}$ to allow recovery from detachment. $10 \mu \mathrm{M}$ ICI-118,551 was added to the cells for $30 \mathrm{~min}$ prior to the addition of norepinephrine (at pre-optimised concentrations). $50 \mu \mathrm{L}$ of serum-free media containing norepinephrine or media alone was added to each well of the 96-well plate and the plate was incubated for $30 \mathrm{~min}$. After $30 \mathrm{~min}, 10,000$ cells/well of cell suspension was added to each well of the 96-well plate [96-well plates pre-coated with human fibronectin $(1.0 \mu \mathrm{g} /$ well $)$, human vitronectin $(0.5 \mu \mathrm{g} /$ well) (R\&D Systems, Minneapolis, MN, USA), or collagen I ( $3 \mathrm{mg} / \mathrm{mL})$ (Thermo Fisher Scientific, Leicester, UK)]. Untreated cells were added to wells containing $50 \mu \mathrm{L}$ of pre-incubated media containing DMSO. Treated cells were added to wells containing $50 \mu \mathrm{L}$ of pre-incubated media containing $10 \mu \mathrm{M}$ norepinephrine. The plate was then incubated for $3 \mathrm{~h}$ at $37^{\circ} \mathrm{C}$ in a humidified atmosphere containing $5 \% \mathrm{CO}_{2}$. The media was removed from each well and the cells washed carefully twice with PBS. The final PBS wash was aspirated, the cells fixed with $4 \%$ paraformaldehyde in PBS and the plate incubated at room temperature for $20 \mathrm{~min}$. The wells were washed twice with PBS. Cells were stained by adding $50 \mu \mathrm{L}$ of crystal violet/cell stain solution and incubated at room temperature for $15 \mathrm{~min}$. Wells were washed twice with deionised water and the last wash aspirated. The wells were allowed to fully dry at room temperature. Once dry, the wells of the plates were scanned using a C.T.L. ELISPOT plate reader and the number of remaining cells counted using ImmunoSpot ${ }^{\circledR}$ software (ImmunoSpot, Bonn, Germany).

\subsection{Cultrex ${ }^{\circledR}$ Cell Migration Assay}

Cells were serum-starved for $24 \mathrm{~h}$ prior to performing the assay. $1 \times 10^{6}$ cells $/ \mathrm{mL}$ in serum-free media (MDA-MB-231, BT-549) or 0.5\% FCS containing media (MDA-MB-468, MCF-7) were added to a $1.5 \mathrm{~mL}$ microtube along with $10 \mu \mathrm{M}$ ICI-118,551. $50 \mu \mathrm{L} /$ well of cell suspension (50,000 cells) with or without antagonists was added to the top chamber of the plate followed by the addition of $150 \mu \mathrm{L}$ of DMEM containing 10\% FCS to the bottom chamber of each well. The cells were incubated for $30 \mathrm{~min}$ prior to the addition of norepinephrine $(10 \mu \mathrm{M})$. The plate was incubated for $24 \mathrm{~h}$ at $37^{\circ} \mathrm{C}$ in a humidified atmosphere containing $5 \% \mathrm{CO}_{2}$. After incubation, the top chamber was inverted and carefully shaken to remove the culture medium and transferred to the black receiver plate. Each well of the top chamber was washed with $100 \mu \mathrm{L}$ of warm $1 \times$ wash buffer and the top chamber inverted and carefully shaken to remove excess wash buffer and placed back into black receiver plate. To the bottom chamber of each well is added $100 \mu \mathrm{L}$ of $1000 \times$ cell dissociation solution/ Calcein AM solution and the plate incubated at $37^{\circ} \mathrm{C}$ in a humidified atmosphere containing $5 \% \mathrm{CO}_{2}$ for $60 \mathrm{~min}$. The plate was read on a fluorescent plate reader at $485 \mathrm{~nm}$ excitation, $520 \mathrm{~nm}$ emission (Tecan Ultra, Mannedorf, Switzerland).

\subsection{CultreCoat ${ }^{\circledR}$ Medium BME Cell Invasion Assay}

Cells were serum-starved for $24 \mathrm{~h}$ prior to performing the assay. $1 \times 10^{6}$ cells $/ \mathrm{mL}$ in serum-free media (MDA-MB-231, BT-549) or 0.5\% FCS containing media (MDA-MB-468, MCF-7) were added to a $1.5 \mathrm{~mL}$ microtube along with $10 \mu \mathrm{M}$ ICI-118,551. $25 \mu \mathrm{L} /$ well of cell suspension (25,000 cells) were added to the top chamber of the plate followed by the addition of $150 \mu \mathrm{L}$ of DMEM containing $10 \%$ FCS to the bottom chamber of each well. The cells were incubated for $30 \mathrm{~min}$ prior to the addition of $10 \mu \mathrm{M}$ norepinephrine. The plate was incubated for $24 \mathrm{~h}$ at $37^{\circ} \mathrm{C}$ in a humidified atmosphere containing $5 \% \mathrm{CO}_{2}$. After incubation the top chamber was washed with $100 \mu \mathrm{L}$ of warm $1 \times$ wash buffer and placed into a black receiver plate. To the bottom chamber of each well $100 \mu \mathrm{L}$ of $1000 \times$ cell dissociation 
solution/Calcein AM solution is added and the plate incubated at $37^{\circ} \mathrm{C}$ in a humidified atmosphere containing $5 \% \mathrm{CO}_{2}$ for $60 \mathrm{~min}$ to fluorescently label and dissociate cells from the membrane. After $60 \mathrm{~min}$, the top chamber was removed and fluorescence was measured using a plate reader (Tecan Ultra, Mannedorf, Switzerland; $485 \mathrm{~nm}$ excitation, $520 \mathrm{~nm}$ emission).

\subsection{Proteomic Analysis}

MDA-MB-231 $\left(1.3 \times 10^{6}\right)$ and MDA-MB-468 $\left(1.2 \times 10^{6}\right)$ cells were seeded and grown to $90 \%$ confluency. On the day of treatment $1 \mathrm{mM}$ stocks of norepinephrine, isoproterenol and ICI-118,551 were made up in serum free DMEM and passed through a $0.22 \mu \mathrm{m}$ filter prior to serial dilution. Media was removed from each flask, and cells were washed three times with PBS. Untreated cells received $25 \mathrm{~mL}$ of serum free DMEM, and treated cells received $25 \mathrm{~mL}$ of DMEM containing $10 \mu \mathrm{M}$ of the appropriate treatment condition. After $30 \mathrm{~min}$ incubation $10 \mu \mathrm{M}$ norepinephrine or $10 \mu \mathrm{M}$ isoproterenol was added into the relevant flasks. Flasks were then incubated at $37^{\circ} \mathrm{C}, 5 \% \mathrm{CO}_{2}$ for $24 \mathrm{~h}$. Twenty four hours after treatment secretome samples were obtained by removing the media and centrifuging $(300 \times g, 5 \mathrm{~min})$, filtered $(0.22 \mu \mathrm{m})$ and concentrated using Amicon Ultra-15 Centrifugal Filter Units (Merck, Kenilworth, NJ, USA). Cell lysates were prepared using 9.5 M urea (Melford, Stowmarket, UK) $/ 2 \%$ v/v dithiothreitol (Melford, Stowmarket, UK)/1\% v/v n-octyl-beta-glycopyranoside (Apollo Scientific Limited, Stockport, UK) containing protease inhibitor (Sigma, Dorset, UK). The lysates were harvested, chilled on ice for $5 \mathrm{~min}$, sonicated for $5 \mathrm{~min}$ and this process was repeated three times before centrifugation for $10 \mathrm{~min}$ at $12,000 \times g$ and storage at $-80^{\circ} \mathrm{C}$.

Cell lysate $(100 \mu \mathrm{g})$ and secretome $(100 \mu \mathrm{g})$ were diluted in $50 \mathrm{mM}$ tri-ethyl ammonium bicarbonate (TEAB) before reduction $\left(5 \mathrm{mM}\right.$ DTT at $56{ }^{\circ} \mathrm{C}$ for $\left.20 \mathrm{~min}\right)$ and alkylation $(15 \mathrm{mM}$ iodoacetamide at room temperature for $15 \mathrm{~min}$ ) and then digested for $16 \mathrm{~h}$ using Trypsin/Lys-C (Promega, Southampton, $\mathrm{UK})$ at $37^{\circ} \mathrm{C}$ at a 20:1 protein:protease ratio $(w / w)$ in a thermomixer (650 rpm) [67]. Next, samples were cleaned up using HyperSep $\mathrm{C}_{18}$ cartridges (Thermo Scientific, Leicester, UK) for solid phase extraction. A vacuum concentrator was then used to concentrate the samples before resuspension in $5 \%$ acetonitrile $+0.1 \%$ formic acid and subsequent analysis of the peptides on an AB Sciex TripleTOF 5600+ MS/MS instrument in both SWATH (Sequential Window Acquisition of All Theoretical Mass Spectra) and IDA (information dependent acquisition) acquisition modes (Sciex, Framingham, MA, USA).

\subsection{Mass Spectrometry}

Each sample was analysed on a Sciex TripleTOF 5600+ mass spectrometer coupled in line with an Eksigent ekspert nano LC 425 system running in micro flow ( $5 \mu \mathrm{L} / \mathrm{min})$ mobile phase B $(100 \%$ acetonitrile $+0.1 \%$ formic acid) over mobile phase $\mathrm{A}(0.1 \%$ formic acid). In brief, $8 \mu \mathrm{g}$ of sample was injected and trapped onto a YMC Triart- $\mathrm{C}_{18}$ pre-column $(5 \mathrm{~mm}, 3 \mu \mathrm{m}, 300 \mu \mathrm{m}$ ID) at a flow rate of $10 \mu \mathrm{L}$ $\min$ for $2 \mathrm{~min}$. The sample was then eluted off the pre-column and onto a YMC Triart- $\mathrm{C}_{18}$ analytical column $(15 \mathrm{~cm}, 2 \mu \mathrm{m}, 300 \mu \mathrm{m}$ ID) that was in line with the Sciex TripleTOF 5600+ Duospray Source using a $50 \mu \mathrm{m}$ electrode in positive mode, $+5500 \mathrm{~V}$. The following linear gradients were used: for SWATH, mobile phase B increasing from $3 \%$ to $30 \%$ over $38 \mathrm{~min}, 30 \%$ to $40 \%$ over $5 \mathrm{~min}, 40 \%$ to $80 \%$ over $2 \mathrm{~min}$ for wash and re-equilibration (total run time $57 \mathrm{~min}$ ). For IDA, mobile phase B increasing from $3 \%$ to $30 \%$ over $68 \mathrm{~min}, 30 \%$ to $40 \%$ over $5 \mathrm{~min}, 40 \%$ to $80 \%$ for column wash and re-equilibration over $2 \mathrm{~min}$ (total run time $87 \mathrm{~min}$ ). Data independent acquisition was performed using 100 variable SWATH windows (optimised on sample type) (TOFMS $\mathrm{m} / \mathrm{z}$ 400-1250) $25 \mathrm{~ms}$ accumulation time; $2.6 \mathrm{~s}$ cycle and IDA with a top 30 ion fragmentation (TOFMS $m / z$ 400-1250) followed by $15 \mathrm{~s}$ exclusion using rolling collision energy, $50 \mathrm{~ms}$ accumulation time; $1.8 \mathrm{~s}$ cycle.

Spectral library generation, alignment and fold change analysis were performed as described previously [68]. In brief, IDA data were searched using ProteinPilot 5.0 (iodoacetamide alkylation, biological modifications emphasised in a thorough search) against the Swiss-Prot human database (June 2017). The Sciex OneOmics software was used to analyse the SWATH data following extraction against 
the locally generated library with the following parameters; 12 peptides per protein, six transitions per peptide, XIC width $30 \mathrm{ppm}, 6$ min retention time window.

\subsection{LYPD3 Protein Expression}

Mass spectrometry and curated protein profiling of the two basal-type cell lines (MDA-MB-231 and MDA-MB-468) identified increased LYPD3 expression, a pro-metastasis protein. LYPD3 protein expression in breast cancer tissue was confirmed by immunostaining three wax-embedded TMA slides (BC081120b, BC10010d, BR1201) comprising 260 cases of invasive ductal adenocarcinoma, 50 cases of metastatic adenocarcinoma and 10 cases of normal breast tissue (U.S Biomax, Rockville, MD, USA).

Sections were immunostained using a monoclonal rabbit anti-human LYPD3 antibody (Supplementary Materials Table S3) on a BenchMark ULTRA stainer (Ventana Medical System, Inc, Oro Valley, AZ, USA) with ultraView Detection Kit (Ventana Medical, Oro Valley, AZ, USA).

The intensity of LYPD3 immunostaining was microscopically assessed for cytoplasmic staining using a five-point scoring technique, where a score of 0 represented nil staining; a score of 1 : weak; 2 : moderate; 3: strong; 4: strong cytoplasmic staining with additional cell membrane staining.

The association between LYPD3 expression and clinical variables in malignant adenocarcinoma, metastasis and adjacent normal breast tissue was statistically tested using SPSS (Version 24, IBM, UK). Immunohistochemistry scores were dichotomously categorised $(0,1=$ negative; $2,3,4=$ positive) for Chi-square tests. Significance levels were $p=0.05$ or less.

\subsection{Western Blot}

Total cell lysates were used from the proteomic analysis. In brief, $50 \mu \mathrm{g}$ of total protein from each sample was prepared with sample reducing buffer $(60 \mathrm{mM}$ Tris- $\mathrm{HCl}$ ( $\mathrm{pH}$ 6.8), $2 \%$ SDS (sodium dodecyl sulphate), $10 \%$ glycerol and $0.01 \%$ bromophenol blue) at a ratio of 1:3 sample vs. reducing buffer. The sample was resolved on an SDS gel (10\% resolving gel, $5 \%$ stacking gel) with Tris/glycine/SDS gel running buffer (Geneflow) at a constant voltage of $150 \mathrm{~V}$. After separation, samples were transferred onto nitrocellulose membranes using Tris/glycine/methanol transfer buffer at a constant current of $180 \mathrm{~mA}$ for $75 \mathrm{~min}$ at $4{ }^{\circ} \mathrm{C}$. Membranes were blocked in $10 \%$ Marvel $^{\mathrm{TM}}$ dried skimmed milk powder for $1 \mathrm{~h}$ before being probed with rabbit anti-LYPD3 antibody (1:1000, ab151709, Abcam, Cambridge, UK), rabbit anti-beta 2 adrenergic receptor antibody (1:1000, ab182136, Abcam, Cambridge, UK) and rabbit anti-beta actin antibody (1:5000, ab8227, Abcam, Cambridge, UK) overnight at $4{ }^{\circ} \mathrm{C}$. The membranes were then washed and goat anti-rabbit IgG HRP-linked antibody was added (1:1000, Cell Signalling Technology, London, UK). Membranes were washed and exposed to the Clarity Western ECL Substrate (1:1) and imaged using a Syngene G:Box and Genesys v1.5.4.0 software (Syngene, Cambridge, UK).

\subsection{Generation of LYPD3 Knockdown Cell Line}

Lentiviral shRNA plasmids and packaging mix (SHP001) were purchased from Sigma (Dorset, UK): shLYPD3 (catalogue number: SHC204) and shControl (catalogue number: SHCLNV-NM_133743). MCF-7 cells $\left(2.5 \times 10^{5}\right)$ were transfected with shRNAs and hexadimethrine bromide (Sigma, H9268) at a final concentration of $8 \mu \mathrm{g} / \mathrm{mL}$ for $18 \mathrm{~h}$. Resistant colonies were selected using media containing $2 \mu \mathrm{g} / \mathrm{mL}$ puromycin.

\subsection{In Silico Gene Expression Profiling}

LYPD3 gene expression profiling was performed using patient gene expression profiles generated through The Cancer Genome Atlas (TCGA) [69] and the Genotype-Tissue Expression (GTEx) project [70] and data was assessed via the Gene Expression Profiling Interactive Analysis (GEPIA) [23]. 


\section{Conclusions}

For the first time, this study postulates that ADR $\beta 2$ signalling can regulate LYPD3. Furthermore, by knocking down LYPD3 expression in the MCF-7 breast cancer cell line we demonstrated that LYPD3 supports both basal and norepinephrine-induced cell migration. Thus, its level of expression could be an important indicator of breast tumour progression and this was supported by our findings in breast cancer tissue cohorts. This highlights LYPD3 as a promising therapeutic target but also supports the development of novel beta-blocker compounds that could be used prophylactically to try and reduce metastatic spread.

Availability of Data and Materials: The mass spectrometry proteomics data that support the findings of this study have been deposited to the ProteomeXchange Consortium [71] via the PRIDE partner repository [72] with the dataset identifier PXD009488. All other data generated or analysed during this study are included in this published article (and its supplementary information files).

Supplementary Materials: The following are available online at http://www.mdpi.com/2079-7737/9/2/39/s1. Figure S1: Survival of breast cancer cells in response to norepinephrine alone, ICI-118,551 alone or in combination with norepinephrine. Cell survival was assessed after concomitant treatment with norepinephrine and ICI-118,551 and was found to be significantly increased in MDA-MB-468 $(p<0.01)$ and ER-positive MCF-7 breast cancer cells $(p<0.05)$. No significant difference was seen in MDA-MB-231 and BT-549 cells. Figure S2: Adhesion of breast cancer cells to fibronectin coated tissue culture plastic following norepinephrine treatment. (A,B) MDA-MB-468 cells, (C,D) MDA-MB-231 cells, (E,F) BT-549 cells and (G,H) MCF-7 cells. Norepinephrine increased the adhesion of all breast cancer cell lines to a fibronectin coated surface. This was statistically significant in all cell lines at the $0.1 \mu \mathrm{M}$ and $0.001 \mu \mathrm{M}$ concentrations. Furthermore, as the concentration on norepinephrine decreases the adhesion of breast cancer cells to the fibronectin coated surface increases in all cell lines. Figure S3: Treatment of breast cancer cells with ICI-118,551 and norepinephrine. Cell migration using a scratch assay was assessed after concomitant treatment with norepinephrine and ICI-118,551. At the $10 \mu \mathrm{M}$ ICI-118,551 concentration, cell migration was significantly decreased in the MDA-MB-468, BT-549 and MCF-7 breast cancer cell lines $(p<0.01)$. Figure S4: (A) Peptide sequences used for quantitation identified from the LYPD3 protein following NE/ISO vs. UT treatment of MDA-MB-468 breast cancer cells and preparation of cell lysates. (B) Peptide sequences used for quantitation identified from the LYPD3 protein following NE/ICI-118,551+NE vs. UT treatment of MDA-MB-468 breast cancer cells and preparation of cell secretome. Figure S5: $50 \mu \mathrm{g}$ protein from the following samples was analysed for LYPD3 protein expression using western blotting; (from left to right) MCF-7 vehicle alone, MCF-7 vehicle and norepinephrine, shControl alone, shControl alone and norepinephrine, shLYPD3 alone, shLYPD3 alone and norepinephrine. Table S1: Enriched GO biological processes for MDA-MB-468 and MDA-MB-231 cells following norepinephrine stimulation. (A) MDA-MB-468 cells. (B) MDA-MB-231 cells. Table S2: Primer sequences used for qRT-PCR. Table S3: Antibody details for FACS and immunohistochemistry. Table S4: Normalised MS protein expression data for all identified proteins.

Author Contributions: Conceptualisation, R.C.R., A.G.P., A.K.M. and D.G.P.; Data curation, A.K.M.; Formal analysis, D.C., J.D.W., A.K.M. and D.G.P.; Funding acquisition, R.C.R., A.G.P. and J.D.W.; Investigation, M.G. and D.C.; Methodology, M.G., D.C., C.C., D.J.B., S.W., L.K., A.C.G., J.D.W. and A.K.M.; Project administration, J.D.W., A.K.M. and D.G.P.; Resources, L.K. and J.D.W.; Software, C.C., D.J.B., S.W. and L.K.; Supervision, R.C.R., A.G.P., A.C.G., J.D.W., A.K.M. and D.G.P.; Writing-original draft, A.K.M.; Writing-review and editing, M.G., D.C., C.C., D.J.B., S.W., R.C.R., A.G.P., A.C.G., J.D.W. and D.G.P. All authors have read and agreed to the published version of the manuscript.

Funding: The John van Geest Cancer Research Centre, Nottingham Trent University Vice Chancellor's Bursary Scheme. Healthcare and Bioscience iNET phase III project through the East Midlands European Regional Development Fund. We acknowledge support from the Air Force Office of Scientific Research which provided access to the Tecan Ultra Fluorescent Plate Reader (C. C. Perry. via FA9550-13-1-0040), and the Nottingham University Hospitals Special Trustees.

Acknowledgments: The authors acknowledge the assistance of Claire Hawkes in Cellular Pathology and Nottingham University Hospitals Trust for assistance with the immunohistochemistry.

Conflicts of Interest: The authors declare no conflict of interest. 


\section{Abbreviations}

$\begin{array}{ll}\text { GPCR } & \text { g-protein coupled receptor } \\ \text { qPCR } & \text { polymerase chain reaction } \\ \text { MFI } & \text { mean fluorescence intensity } \\ \text { FCS } & \text { foetal calf serum } \\ \text { PFS } & \text { progression free survival } \\ \text { ADR } \beta & \text { beta-adrenergic receptor } \\ \text { BME } & \text { basement membrane extract } \\ \text { LCMS } & \text { liquid chromatography mass spectrometry } \\ \text { SWATH-MS } & \text { sequential window acquisition of all theoretical mass spectra } \\ \text { LYPD3 } & \text { ly6/PLAUR domain-containing protein 3 precursor } \\ \text { TMA } & \text { tumour microarray } \\ \text { cAMP } & \text { cyclic adenosine monophosphate } \\ \text { NE } & \text { norepinephrine } \\ \text { ISO } & \text { isoproterenol } \\ \text { UT } & \text { untreated } \\ \text { EMT } & \text { epithelial to mesenchymal transition } \\ \text { GPI } & \text { glycosyl-phosphatidyl-inositol } \\ \text { CREB } & \text { cAMP response element binding protein } \\ \text { ATP } & \text { adenosine triphosphate } \\ \text { PKA } & \text { protein kinase A } \\ \text { LAMC1 } & \text { laminin subunit gamma 1 } \\ \text { MMP } & \text { matrix metallopeptidase } \\ \text { uPAR } & \text { urokinase-type plasminogen activator receptor } \\ \text { NE } & \text { norepinephrine } \\ \text { SWATH } & \text { Sequential Window Acquisition of All Theoretical Mass Spectra } \\ \text { IDA } & \text { information dependent acquisition } \\ \text { HKG } & \text { house keeping gene } \\ \text { ANOVA } & \text { analysis of variance } \\ \text { EDTA } & \text { ethylenediaminetetraacetic acid } \\ \text { SDS } & \text { sodium dodecyl sulphate } \\ & \end{array}$

\section{References}

1. Steeg, P.S. Targeting metastasis. Nat. Rev. Cancer 2016, 16, 201-218. [CrossRef]

2. Fidler, I.J. The pathogenesis of cancer metastasis: The "seed and soil" hypothesis revisited. Nat. Rev. Cancer 2003, 3, 453-458. [CrossRef] [PubMed]

3. Cakir, Y.; Plummer, H.K.; Tithof, P.K.; Schuller, H.M. Beta-adrenergic and arachidonic acid-mediated growth regulation of human breast cancer cell lines. Int. J. Oncol. 2002, 21, 153-157. [CrossRef] [PubMed]

4. Lüthy, I.A.; Bruzzone, A.; Piñero, C.P.; Castillo, L.F.; Chiesa, I.J.; Vázquez, S.M.; Sarappa, M.G. Adrenoceptors: Non conventional target for breast cancer? Curr. Med. Chem. 2009, 16, 1850-1862. [CrossRef] [PubMed]

5. Powe, D.G.; Entschladen, F. Targeted therapies: Using $\beta$-blockers to inhibit breast cancer progression. Nat. Rev. Clin. Oncol. 2011, 8, 511-512. [CrossRef]

6. Campbell, J.P.; Karolak, M.R.; Ma, Y.; Perrien, D.S.; Masood-Campbell, S.K.; Penner, N.L.; Munoz, S.A.; Zijlstra, A.; Yang, X.; Sterling, J.A.; et al. Stimulation of host bone marrow stromal cells by sympathetic nerves promotes breast cancer bone metastasis in mice. PLoS Biol. 2012, 10, e1001363. [CrossRef]

7. Strell, C.; Niggemann, B.; Voss, M.J.; Powe, D.G.; Zänker, K.S.; Entschladen, F. Norepinephrine promotes the $\beta 1$-integrin-mediated adhesion of MDA-MB-231 cells to vascular endothelium by the induction of a GRO $\alpha$ release. Mol. Cancer Res. 2012, 10, 197-207. [CrossRef]

8. Kim, T.-H.; Gill, N.K.; Nyberg, K.D.; Nguyen, A.V.; Hohlbauch, S.V.; Geisse, N.A.; Nowell, C.J.; Sloan, E.K.; Rowat, A.C. Cancer cells become less deformable and more invasive with activation of $\beta$-adrenergic signaling. J. Cell Sci. 2016, 14, jcs.194803. [CrossRef] 
9. Sloan, E.K.; Priceman, S.J.; Cox, B.F.; Yu, S.; Pimentel, M.A.; Tangkanangnukul, V.; Arevalo, J.M.; Morizono, K.; Karanikolas, B.D.; Wu, L.; et al. The sympathetic nervous system induces a metastatic switch in primary breast cancer. Cancer Res. 2010, 70, 7042-7052. [CrossRef]

10. Powe, D.G.; Voss, M.J.; Zänker, K.S.; Habashy, H.O.; Green, A.R.; Ellis, I.O.; Entschladen, F. Beta-blocker drug therapy reduces secondary cancer formation in breast cancer and improves cancer specific survival. Oncotarget 2010, 1, 628-638. [CrossRef]

11. Barron, T.I.; Connolly, R.M.; Sharp, L.; Bennett, K.; Visvanathan, K. Beta blockers and breast cancer mortality: A population- based study. J. Clin. Oncol. 2011, 29, 2635-2644. [CrossRef] [PubMed]

12. Melhem-Bertrandt, A.; Chavez-Macgregor, M.; Lei, X.; Brown, E.N.; Lee, R.T.; Meric-Bernstam, F.; Sood, A.K.; Conzen, S.D.; Hortobagyi, G.N.; Gonzalez-Angulo, A.M. Beta-blocker use is associated with improved relapse-free survival in patients with triple-negative breast cancer. J. Clin. Oncol. 2011, 29, 2645-2652. [CrossRef] [PubMed]

13. Kalinsky, K. Study of Propranolol in Newly Diagnosed Breast Cancer Patients Undergoing Neoadjuvant Chemotherapy. Available online: https://clinicaltrials.gov (accessed on 1 December 2018).

14. Allweiss, T. Perioperative Administration of COX2 Inhibitors and Beta-Blockers to Women Undergoing Breast Cancer Surgery. 2007. Available online: https://clinicaltrials.gov (accessed on 1 December 2018).

15. Neoadjuvant Propranolol in Breast Cancer. 2015. Available online: https://clinicaltrials.gov1 (accessed on 1 December 2018).

16. Carson, W. Propranolol Hydrochloride in Treating Patients with Locally Recurrent or Metastatic Solid Tumours That Cannot be Removed by Surgery. 2013. Available online: https://clinicaltrials.gov (accessed on 1 December 2018).

17. Cardwell, C.R.; Coleman, H.G.; Murray, L.J.; Entschladen, F.; Powe, D.G. Beta-blocker usage and breast cancer survival: A nested case-control study within a UK clinical practice research datalink cohort. Int. J. Epidemiol. 2013, 42, 1852-1861. [CrossRef] [PubMed]

18. Yap, A.; Lopez-Olivo, M.A.; Dubowitz, J.; Pratt, G.; Hiller, J.; Gottumukkala, V.; Sloan, E.; Riedel, B.; Schier, R. Effect of beta-blockers on cancer recurrence and survival: A meta-analysis of epidemiological and perioperative studies. Br. J. Anaesth. 2018, 121, 45-57. [CrossRef]

19. Carie, A.E.; Sebti, S.M. A chemical biology approach identifies a beta-2 adrenergic receptor agonist that causes human tumor regression by blocking the Raf-1/Mek-1/Erk1/2 pathway. Oncogene 2007, 26, 3777-3788. [CrossRef]

20. Paret, C.; Hildebrand, D.; Weitz, J.; Kopp-Schneider, A.; Kuhn, A.; Beer, A.; Hautmann, R.; Zöller, M. C4.4A as a candidate marker in the diagnosis of colorectal cancer. Br. J. Cancer 2007, 97, 1146-1156. [CrossRef]

21. Fletcher, G.C.; Patel, S.; Tyson, K.; Adam, P.J.; Schenker, M.; Loader, J.A.; Daviet, L.; Legrain, P.; Parekh, R.; Harris, A.L.; et al. hAG-2 and hAG-3, human homologues of genes involved in differentiation, are associated with oestrogen receptor-positive breast tumours and interact with metastasis gene C4.4A and dystroglycan. Br. J. Cancer 2003, 88, 579-585. [CrossRef]

22. Jacobsen, B.; Kriegbaum, M.C.; Santoni-Rugiu, E.; Ploug, M. C4.4A as a biomarker in pulmonary adenocarcinoma and squamous cell carcinoma. World J. Clin. Oncol. 2014, 5, 621-632. [CrossRef]

23. Tang, Z.; Li, C.; Kang, B.; Gao, G.; Li, C.; Zhang, Z. GEPIA: A web server for cancer and normal gene expression profiling and interactive analyses. Nucleic Acids Res. 2017, 45, W98-W102. [CrossRef]

24. Qin, J.; Jin, F.; Li, N.; Guan, H.; Lan, L.; Ni, H.; Wang, Y. Adrenergic receptor $\beta 2$ activation by stress promotes breast cancer progression through macrophages M2 polarization in tumor microenvironment. BMB Rep. 2015, 48, 295-300. [CrossRef]

25. Pon, C.K.; Lane, J.R.; Sloan, E.K.; Halls, M.L. The 2-adrenoceptor activates a positive cAMP-calcium feedforward loop to drive breast cancer cell invasion. FASEB J. 2016, 30, 1144-1154. [CrossRef] [PubMed]

26. Creed, S.J.; Le, C.P.; Hassan, M.; Pon, C.K.; Albold, S.; Chan, K.T.; Berginski, M.E.; Huang, Z.; Bear, J.E.; Lane, J.R. $\beta 2$-adrenoceptor signaling regulates invadopodia formation to enhance tumor cell invasion. Breast Cancer Res. 2015, 17, 145. [CrossRef] [PubMed]

27. Chang, A.; Le, C.P.; Walker, A.K.; Creed, S.J.; Pon, C.K.; Albold, S.; Carroll, D.; Halls, M.L.; Lane, J.R.; Riedel, B.; et al. $\beta 2$-Adrenoceptors on tumor cells play a critical role in stress-enhanced metastasis in a mouse model of breast cancer. Brain Behav. Immun. 2016, 57, 106-115. [CrossRef] [PubMed] 
28. Madden, K.S.; Szpunar, M.J.; Brown, E.B. $\beta$-Adrenergic receptors ( $\beta$-AR) regulate VEGF and IL-6 production by divergent pathways in high $\beta$-AR-expressing breast cancer cell lines. Breast Cancer Res. Treat. 2011, 130, 747-758. [CrossRef]

29. Pasquier, E.; Ciccolini, J.; Carre, M.; Giacometti, S.; Fanciullino, R.; Pouchy, C.; Montero, M.P.; Serdjebi, C.; Kavallaris, M.; Andre, N. Propranolol potentiates the anti-angiogenic effects and anti-tumor efficacy of chemotherapy agents: Implication in breast cancer treatment. Oncotarget 2011, 2, 797-809. [CrossRef]

30. Chen, H.; Liu, D.; Yang, Z.; Sun, L.; Deng, Q.; Yang, S.; Qian, L.; Guo, L.; Yu, M.; Hu, M.; et al. Adrenergic signaling promotes angiogenesis through endothelial cell-tumor cell crosstalk. Endocr. Relat. Cancer 2014, 21, 783-795. [CrossRef]

31. Sastry, K.S.R.; Karpova, Y.; Prokopovich, S.; Smith, A.J.; Essau, B.; Gersappe, A.; Carson, J.P.; Weber, M.J.; Register, T.C.; Chen, Y.Q.; et al. Epinephrine Protects Cancer Cells from Apoptosis via Activation of cAMP-dependent Protein Kinase and BAD Phosphorylation. J. Biol. Chem. 2007, 282, 14094-14100. [CrossRef]

32. Lutgendorf, S.K.; Sood, A.K.; Antoni, M.H. Host factors and cancer progression: Biobehavioral signaling pathways and interventions. J. Clin. Oncol. 2010, 28, 4094-4099. [CrossRef]

33. Reeder, A.; Attar, M.; Nazario, L.; Bathula, C.; Zhang, A.; Hochbaum, D.; Roy, E.; Cooper, K.L.; Oesterreich, S.; Davidson, N.E.; et al. Stress hormones reduce the efficacy of paclitaxel in triple negative breast cancer through induction of DNA damage. Br. J. Cancer 2015, 112, 1461-1470. [CrossRef]

34. Powe, D.G.; Voss, M.J.; Habashy, H.O.; Zänker, K.S.; Green, A.R.; Ellis, I.O.; Entschladen, F. Alpha- and beta-adrenergic receptor (AR) protein expression is associated with poor clinical outcome in breast cancer: An immunohistochemical study. Breast Cancer Res. Treat. 2011, 130, 457-463. [CrossRef]

35. Lee, J.Y.; Park, K.; Lee, E.; Ahn, T.; Jung, H.H.; Lim, S.H.; Hong, M.; Do, I.G.; Cho, E.Y.; Kim, D.H.; et al. Gene Expression Profiling of Breast Cancer Brain Metastasis. Sci Rep. 2016, 6, 28623. [CrossRef] [PubMed]

36. Gargiulo, L.; Copsel, S.; Rivero, E.M.; Galés, C.; Sénard, J.-M.; Lüthy, I.A.; Davio, C.; Bruzzone, A. Differential $\beta_{2}$-adrenergic receptor expression defines the phenotype of non-tumorigenic and malignant human breast cell lines. Oncotarget 2014, 5, 10058-10069. [CrossRef] [PubMed]

37. Gargiulo, L.; May, M.; Rivero, E.M.; Copsel, S.; Lamb, C.; Lydon, J.; Davio, C.; Lanari, C.; Lüthy, I.A.; Bruzzone, A. A Novel Effect of $\beta$-Adrenergic Receptor on Mammary Branching Morphogenesis and its Possible Implications in Breast Cancer. J. Mammary Gland Biol. Neoplasia 2017, 22, 43-57. [CrossRef] [PubMed]

38. Slotkin, T.A.; Zhang, J.; Dancel, R.; Garcia, S.J.; Willis, C.; Seidler, F.J. Beta-adrenoceptor signaling and its control of cell replication in MDA-MB-231 human breast cancer cells. Breast Cancer Res. Treat. 2000, 60, 153-166. [CrossRef] [PubMed]

39. Pérez Piñero, C.; Bruzzone, A.; Sarappa, M.G.; Castillo, L.F.; Lüthy, I.A. Involvement of $\alpha 2-$ and $\beta 2$-adrenoceptors on breast cancer cell proliferation and tumour growth regulation. Br. J. Pharmacol. 2012, 166, 721-736. [CrossRef] [PubMed]

40. Lang, K.; Drell, T.L.; Lindecke, A.; Niggemann, B.; Kaltschmidt, C.; Zaenker, K.S.; Entschladen, F. Induction of a metastatogenic tumor cell type by neurotransmitters and its pharmacological inhibition by established drugs. Int. J. Cancer 2004, 112, 231-238. [CrossRef] [PubMed]

41. Shi, M.; Liu, D.; Duan, H.; Qian, L.; Wang, L.; Niu, L.; Zhang, H.; Yong, Z.; Gong, Z.; Song, L.; et al. The $\beta 2$-adrenergic receptor and Her2 comprise a positive feedback loop in human breast cancer cells. Breast Cancer Res. Treat. 2011, 125, 351-362. [CrossRef]

42. Choy, C.; Raytis, J.L.; Smith, D.D.; Duenas, M.; Neman, J.; Jandial, R.; Lew, M.W. Inhibition of $\beta 2$-adrenergic receptor reduces triple-negative breast cancer brain metastases: The potential benefit of perioperative $\beta$-blockade. Oncol. Rep. 2016, 35, 3135-3142. [CrossRef]

43. Boulay, G.; Malaquin, N.; Loison, I.; Foveau, B.; Van Rechem, C.; Rood, B.R.; Pourtier, A.; Leprince, D. Loss of Hypermethylated in Cancer 1 (HIC1) in Breast Cancer Cells Contributes to Stress-induced Migration and Invasion through $\beta-2$ Adrenergic Receptor (ADRB2) Misregulation. J. Biol. Chem. 2012, 287, 5379-5389. [CrossRef]

44. Hanahan, D.; Weinberg, R.A. Hallmarks of cancer: The next generation. Cell 2011, 144, 646-674. [CrossRef]

45. Cole, S.W.; Sood, A.K. Molecular pathways: Beta-adrenergic signaling in cancer. Clin. Cancer Res. 2012, 18, 1201-1206. [CrossRef] [PubMed]

46. Entschladen, F.; Drell, T.L.; Lang, K.; Joseph, J.; Zaenker, K.S. Tumour-cell migration, invasion, and metastasis: Navigation by neurotransmitters. Lancet Oncol. 2004, 5, 254-258. [CrossRef] 
47. Lavoie, C.; Mercier, J.-F.; Salahpour, A.; Umapathy, D.; Breit, A.; Villeneuve, L.-R.; Zhu, W.Z.; Xiao, R.P.; Lakatta, E.G.; Bouvier, M.; et al. $\beta 1 / \beta 2$-adrenergic receptor heterodimerization regulates beta 2-adrenergic receptor internalization and ERK signaling efficacy. J. Biol. Chem. 2002, 277, 35402-35410. [CrossRef] [PubMed]

48. Hague, C.; Uberti, M.A.; Chen, Z.; Hall, R.A.; Minneman, K.P. Cell surface expression of alpha1D-adrenergic receptors is controlled by heterodimerization with alpha1B-adrenergic receptors. J. Biol. Chem. 2004, 279, 15541-15549. [CrossRef] [PubMed]

49. Small, K.M.; Schwarb, M.R.; Glinka, C.; Theiss, C.T.; Brown, K.M.; Seman, C.A.; Liggett, S.B. $\alpha_{2 A^{-}}$and $\alpha_{2 C}$-adrenergic receptors form homo- and heterodimers: The heterodimeric state impairs agonist-promoted GRK phosphorylation and beta-arrestin recruitment. Biochemistry 2006, 45, 4760-4767. [CrossRef] [PubMed]

50. Tyurin-Kuzmin, P.A.; Fadeeva, J.I.; Kanareikina, M.A.; Kalinina, N.I.; Sysoeva, V.Y.; Dyikanov, D.T.; Stambolsky, D.V.; Tkachuk, V.A. Activation of $\beta$-adrenergic receptors is required for elevated $\alpha 1 \mathrm{~A}$-adrenoreceptors expression and signaling in mesenchymal stromal cells. Sci. Rep. 2016, 6, 32835. [CrossRef]

51. Uberti, M.A.; Hague, C.; Oller, H.; Minneman, K.P.; Hall, R.A. Heterodimerization with beta2-adrenergic receptors promotes surface expression and functional activity of alpha1D-adrenergic receptors. J. Pharmacol. Exp. Ther. 2005, 313, 16-23. [CrossRef]

52. Xu, J.; He, J.; Castleberry, A.M.; Balasubramanian, S.; Lau, A.G.; Hall, R.A. Heterodimerization of alpha 2Aand beta 1-adrenergic receptors. J. Biol. Chem. 2003, 278, 10770-10777. [CrossRef]

53. Hague, C.; Lee, S.E.; Chen, Z.; Prinster, S.C.; Hall, R.A.; Minneman, K.P. Heterodimers of alpha1B- and alpha1D-adrenergic receptors form a single functional entity. Mol. Pharmacol. 2006, 69, 45-55. [CrossRef]

54. Hansen, L.V.; Gårdsvoll, H.; Nielsen, B.S.; Lund, L.R.; Danø, K.; Jensen, O.N.; Ploug, M. Structural analysis and tissue localization of human C4.4A: A protein homologue of the urokinase receptor. Biochem. J. 2004, 380 Pt 3, 845-857. [CrossRef]

55. Würfel, J.; Seiter, S.; Stassar, M.; Claas, A.; Kläs, R.; Rösel, M.; Marhaba, R.; Savelyeva, L.; Schwab, M.; Matzku, S.; et al. Cloning of the human homologue of the metastasis-associated rat C4.4A. Gene 2001, 262, 35-41. [CrossRef]

56. Hansen, L.V.; Skov, B.G.; Ploug, M.; Pappot, H. Tumour cell expression of C4.4A, a structural homologue of the urokinase receptor, correlates with poor prognosis in non-small cell lung cancer. Lung Cancer 2007, 58, 260-266. [CrossRef] [PubMed]

57. Hansen, L.V.; Laerum, O.D.; Illemann, M.; Nielsen, B.S.; Ploug, M. Altered expression of the urokinase receptor homologue, $\mathrm{C} 4.4 \mathrm{~A}$, in invasive areas of human esophageal squamous cell carcinoma. Int. J. Cancer 2008, 122, 734-741. [CrossRef] [PubMed]

58. Jacobsen, B.; Muley, T.; Meister, M.; Dienemann, H.; Christensen, I.J.; Santoni-Rugiu, E.; Lærum, O.D.; Ploug, M. Ly6/uPAR-related protein C4.4A as a marker of solid growth pattern and poor prognosis in lung adenocarcinoma. J. Thorac. Oncol. 2013, 8, 152-160. [CrossRef] [PubMed]

59. Miyake, T.; Ito, T.; Yanai, A.; Inoue, N.; Miyagawa, Y.; Murase, K.; Imamura, M.; Ichii, S.; Takatsuka, Y.; Nishizaki, T.; et al. C4.4A highly expressed in HER2-positive human breast cancers may indicate a good prognosis. Breast Cancer 2015, 22, 366-373. [CrossRef] [PubMed]

60. Ngora, H.; Galli, U.M.; Miyazaki, K.; Zöller, M. Membrane-bound and exosomal metastasis-associated C4.4A promotes migration by associating with the $\alpha(6) \beta(4)$ integrin and MT1-MMP. Neoplasia 2012, 14, 95-107. [CrossRef] [PubMed]

61. Gu, Y.; Lin, S.; Li, J.-L.; Nakagawa, H.; Chen, Z.; Jin, B.; Tian, L.; Ucar, D.A.; Shen, H.; Lu, J.; et al. Altered LKB1/CREB-regulated transcription co-activator (CRTC) signaling axis promotes esophageal cancer cell migration and invasion. Oncogene 2012, 31, 469-479. [CrossRef]

62. Esselens, C.W.; Malapeira, J.; Colomé, N.; Moss, M.; Canals, F.; Arribas, J. Metastasis-associated C4.4A, a GPI-anchored protein cleaved by ADAM10 and ADAM17. Biol Chem. 2008, 389, 1075-1084. [CrossRef]

63. Thuma, F.; Ngora, H.; Zöller, M. The metastasis-associated molecule C4.4A promotes tissue invasion and anchorage independence by associating with the alpha6beta4 integrin. Mol Oncol. 2013, 7, 917-928. [CrossRef]

64. Smith, H.W.; Marshall, C.J. Regulation of cell signalling by uPAR. Nat. Rev. Mol. Cell Biol. 2010, 11, 23-36. [CrossRef] 
65. Harner-Foreman, N.; Vadakekolathu, J.; Laversin, S.A.; Mathieu, M.G.; Reeder, S.; Pockley, A.G.; Rees, R.C.; Boocock, D.J. A novel spontaneous model of epithelial-mesenchymal transition (EMT) using a primary prostate cancer derived cell line demonstrating distinct stem-like characteristics. Sci. Rep. 2017, 7, 40633. [CrossRef] [PubMed]

66. Oshiro, R.; Yamamoto, H.; Takahashi, H.; Ohtsuka, M.; Wu, X.; Nishimura, J.; Takemasa, I.; Mizushima, T.; Ikeda, M.; Sekimoto, M.; et al. C4.4A is associated with tumor budding and epithelial-mesenchymal transition of colorectal cancer. Cancer Sci. 2012, 103, 1155-1164. [CrossRef] [PubMed]

67. Vyas, F.S.; Hargreaves, A.J.; Bonner, P.L.R.; Boocock, D.J.; Coveney, C.; Dickenson, J.M. A1 adenosine receptor-induced phosphorylation and modulation of transglutaminase 2 activity in $\mathrm{H} 9 \mathrm{c} 2$ cells: A role in cell survival. Biochem. Pharmacol. 2016, 107, 41-58. [CrossRef] [PubMed]

68. Balahmar, R.M.; Boocock, D.J.; Coveney, C.; Ray, S.; Vadakekolathu, J.; Regad, T.; Ali, S.; Sivasubramaniam, S. Identification and characterisation of NANOG+/ OCT-4high/SOX2+ doxorubicin-resistant stem-like cells from transformed trophoblastic cell lines. Oncotarget 2018, 9, 7054. [CrossRef]

69. Available online: https://www.cancer.gov/tcga (accessed on 14 March 2018).

70. Available online: https://gtexportal.org/home/ (accessed on 14 March 2018).

71. Deutsch, E.W.; Csordas, A.; Sun, Z.; Jarnuczak, A.; Perez-Riverol, Y.; Ternent, T.; Ternent, T.; Campbell, D.S.; Bernal-Llinares, M.; Okuda, S.; et al. The ProteomeXchange consortium in 2017: Supporting the cultural change in proteomics public data deposition. Nucleic Acids Res. 2017, 45, D1100-D1106. [CrossRef]

72. Vizcaíno, J.A.; Csordas, A.; Del-Toro, N.; Dianes, J.A.; Griss, J.; Lavidas, I.; Mayer, G.; Perez-Riverol, Y.; Reisinger, F.; Ternent, T.; et al. 2016 update of the PRIDE database and its related tools. Nucleic Acids Res. 2016, 44, D447-D456. [CrossRef]

(C) 2020 by the authors. Licensee MDPI, Basel, Switzerland. This article is an open access article distributed under the terms and conditions of the Creative Commons Attribution (CC BY) license (http://creativecommons.org/licenses/by/4.0/). 